\title{
Future Therapeutic Directions for Smac-Mimetics
}

\author{
Emma Morrish ${ }^{1,2}$, Gabriela Brumatti ${ }^{1,2}$ and John Silke ${ }^{1,2, *(1)}$ \\ 1 Inflammation Division, Walter and Eliza Hall Institute of Medical Research, Melbourne VIC 3052, Australia; \\ morrish.e@wehi.edu.au (E.M.); brumatti@wehi.edu.au (G.B.) \\ 2 Department of Medical Biology, University of Melbourne, Melbourne VIC 3010, Australia \\ * Correspondence: silke@wehi.edu.au
}

Received: 21 January 2020; Accepted: 7 February 2020; Published: 11 February 2020

\begin{abstract}
It is well accepted that the ability of cancer cells to circumvent the cell death program that untransformed cells are subject to helps promote tumor growth. Strategies designed to reinstate the cell death program in cancer cells have therefore been investigated for decades. Overexpression of members of the Inhibitor of APoptosis (IAP) protein family is one possible mechanism hindering the death of cancer cells. To promote cell death, drugs that mimic natural IAP antagonists, such as second mitochondria-derived activator of caspases (Smac/DIABLO) were developed. Smac-Mimetics (SMs) have entered clinical trials for hematological and solid cancers, unfortunately with variable and limited results so far. This review explores the use of SMs for the treatment of cancer, their potential to synergize with up-coming treatments and, finally, discusses the challenges and optimism facing this strategy.
\end{abstract}

Keywords: Smac/DIABLO; Smac-Mimetics; IAPs; TNF; cell death; cancer

\section{The Relevance of Programmed Cell Death in Cancer}

One of the hallmarks of cancer is failure to undergo genetically programmed cell death in response to signals that would normally promote a suicide response in untransformed cells. Numerous programmed cell death mechanisms have been described and include apoptosis, necroptosis, autophagic cell death, eryptosis, NETosis, ferroptosis, paraptosis and pyroptosis [1]. The most important of these in cancer development are apoptosis and necroptosis. While autophagy very likely helps cancer cells survive low nutrient and other stressful conditions, and there are several well-known instances of autophagic cell death during development, the importance of autophagic cell death in tumor development is still unclear [1,2]. Failure to undergo cell death allows cancer cells to mutate, evolve and proliferate. Therefore, reactivating their ability to commit suicide is an appealing anti-cancer treatment strategy and has been explored in a variety of chemotherapeutic drug approaches. Apoptosis is one type of programmed cell death which occurs under normal physiological conditions and is described as being either intrinsic (mitochondria dependent) or extrinsic (death receptor dependent) [3]. Apoptosis is characterized morphologically by cell shrinkage, membrane blebbing, aggregation of chromatin and formation of apoptotic bodies. The enzymes that cause these phenotypes are cysteine proteases that cleave after an aspartate residue and are therefore known as caspases [4]. In contrast, necrosis, an unregulated form of cell death, leads to loss of cell homeostasis and membrane integrity, resulting in cell rupture [5,6]. Another form of programmed cell death termed necroptosis, which shares features with necrosis such as cell rupture and release of cellular contents, has recently also been explored as an anti-cancer therapeutic strategy [7,8]. Necroptosis is implemented during cellular stress when caspases are inhibited, for example genetically or pharmacologically. The proteins that carry out the necroptotic program are the Receptor-Interacting serine/threonine-Protein Kinases (RIPK) 1 and 3 and the pseudokinase Mixed Lineage Kinase domain-Like protein (MLKL) [9]. 


\section{Inhibitor of Apoptosis Proteins}

The human family of Inhibitor of APoptosis (IAP) proteins regulates cell survival in response to a number of stimuli. The IAP family, defined by the presence of one or more Baculoviral IAP Repeat (BIR) domains, consists of eight members: X-chromosome-linked IAP (XIAP), cellular IAP 1 and 2 (cIAP1 and cIAP2), Melanoma-IAP (ML-IAP), Neuronal-IAP (NAIP), survivin, BIR-containing ubiquitin-conjugating enzyme (Bruce/Apollon) and IAP-Like Protein 2 (ILP-2). Only three of these, cIAP1, cIAP2 and XIAP, have major anti-apoptotic roles and this review therefore focuses on them (Figure 1) [10-12]. These three proteins contain three BIR domains, a Really Interesting New Gene (RING)-finger domain, that has Ubiquitin (Ub) ligase (E3) activity, and a UB-Associated (UBA) domain, which enables their interaction with ubiquitylated proteins $[13,14]$. XIAP is able to bind and inhibit caspases 3, 7 and 9, whilst cIAP1 and 2 inhibit apoptosis induced by members of the Tumor Necrosis Factor (TNF) Super Family (TNFSF), at least in part by regulating RIPK1, a cytoplasmic protein recruited to TNFSF receptors. XIAP is also essential for Nucleotide-binding Oligomerization Domain-containing protein (NOD) signaling and ubiquitylates the NOD binding protein RIPK2, presumably in a similar manner to the way cIAPs ubiquitylate RIPK1 [15-20]. However, NOD and RIPK2 do not appear to induce cell death and therefore, XIAP function in this pathway is unlikely to be directly anti-apoptotic.

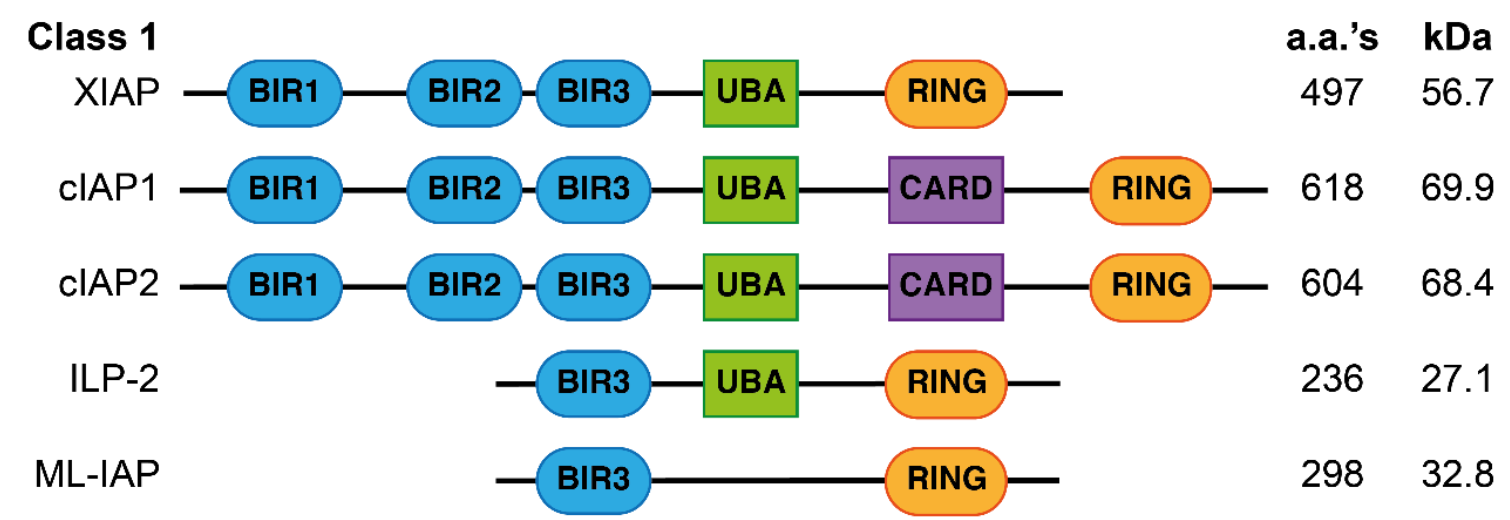

\section{Class 2}

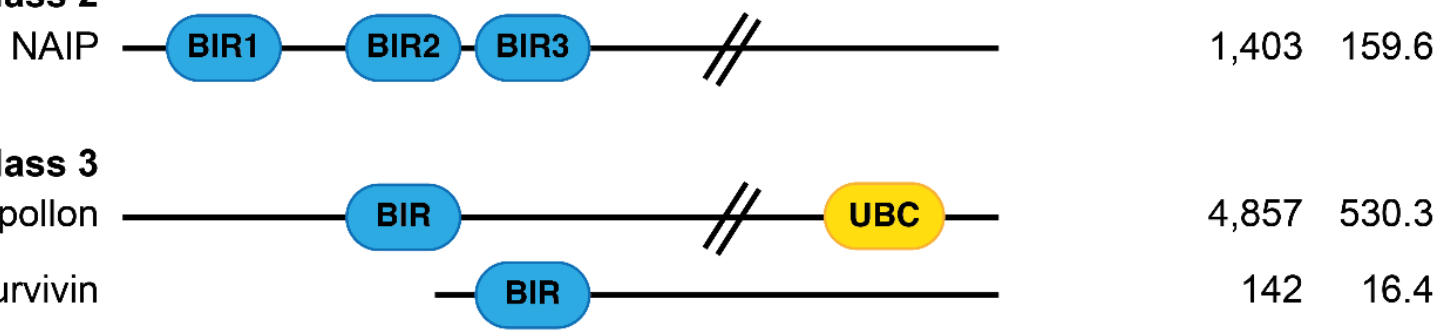

Figure 1. Schematic representation of the structures of the eight-mammalian Inhibitor of APoptosis (IAP) proteins. BIR, Baculovirus IAP repeat domain; UBA, Ubiquitin binding domain; CARD, Caspase recruitment domain; RING, E3-Ligase domain; UBC, E2-Ligase domain; a.a.'s, amino acids; $\mathrm{kDa}$, kilodalton. The position and size of domains are not represented to scale. 


\section{TNF Signaling Pathway}

TNF is a potent and pleiotropic cytokine responsible for a diverse range of biological functions including inflammation, proliferation and cell death. In most cases, the binding of TNF to its receptor, TNFR1, leads to the recruitment of the TNF Receptor-Associated Death Domain (TRADD) and RIPK1 via their respective death domains. TRADD and RIPK1 can apparently bind TNFR1 at the same time, but the relative contribution of each to the signaling complex may depend upon the cell type [21-23]. TRADD can recruit the TNF Receptor-Associated Factor 2 (TRAF2) and cIAP1/2 are bound to TRAF2 via a BIR1 interaction with the coiled coil of a TRAF2 trimer [24,25]. As E3 ubiquitin ligases, cIAP1/2 conjugate components of this complex with ubiquitin. The ubiquitin platform recruits Linear UBiquitin chain Assembly Complex (LUBAC), IkB Kinases (IKKs) and Transforming growth factor beta-Activated Kinase 1 (TAK1), resulting in activation of canonical Nuclear Factor kappa-light-chain-enhancer of activated B cells (NF- $\mathrm{KB}$ ) and Mitogen-Activated Protein Kinases (MAPKs). This leads to transcriptional upregulation and mRNA stabilization of genes that encode mediators of inflammation and proteins involved in cell survival and proliferation [20,26,27]. Although the details are not fully understood, ubiquitylation and phosphorylation of components within this plasma membrane associated, "complex 1", limit the formation of the death-inducing complex 2 (Figure 2) [28-32].

Natural antagonists of IAPs, such as second mitochondria-derived activator of caspases (Smac/DIABLO), or HtrA2, bind to the BIR domains of IAPs via their IAP-Binding Motifs (IBMs). Smac and HtrA2 prevent XIAP from binding and inhibiting caspases 3, 7 and 9 [33-37]. IAP antagonists rarely induce XIAP degradation. However, in many cases, they promote cIAP auto-ubiquitylation and proteasomal degradation $[17,20]$. They do this by unleashing the RING domain of cIAPs from BIR3 inhibition allowing it to dimerize [38,39]. This activation of the E3 ligase function of cIAPs by an IAP antagonist may also result in ubiquitylation of the antagonist but the physiological significance of this is not clear [35,40-42]. IAP antagonist induced degradation of cIAPs prevents cIAP-mediated ubiquitylation of components in the TNF signaling pathway and thus converts TNFR1 signaling from pro-survival to pro-apoptotic. In particular, loss of cIAPs allows the formation of a FADD-caspase-8 containing complex 2, leading to caspase- 8 activation by oligomerizing in a chain like manner [43-45].

In the absence of caspase- 8 activity, for example through pharmacological antagonism or genetic deletion, and in the presence of IAP inhibitors (such as Smac-Mimetic drugs), a second cell death mediating complex forms, termed complex $2 b$. RIPK1 binds with RIPK3 via their Respective Homotypic Interaction Motif (RHIM) domains, leading to auto-phosphorylation and subsequent recruitment of MLKL. RIPK3 phosphorylation and oligomerization of MLKL, leads to its activation and translocation from the cytosol to the plasma membrane, where it disrupts membrane integrity, leading to necroptotic cell death (Figure 2) [26,46-49]. 


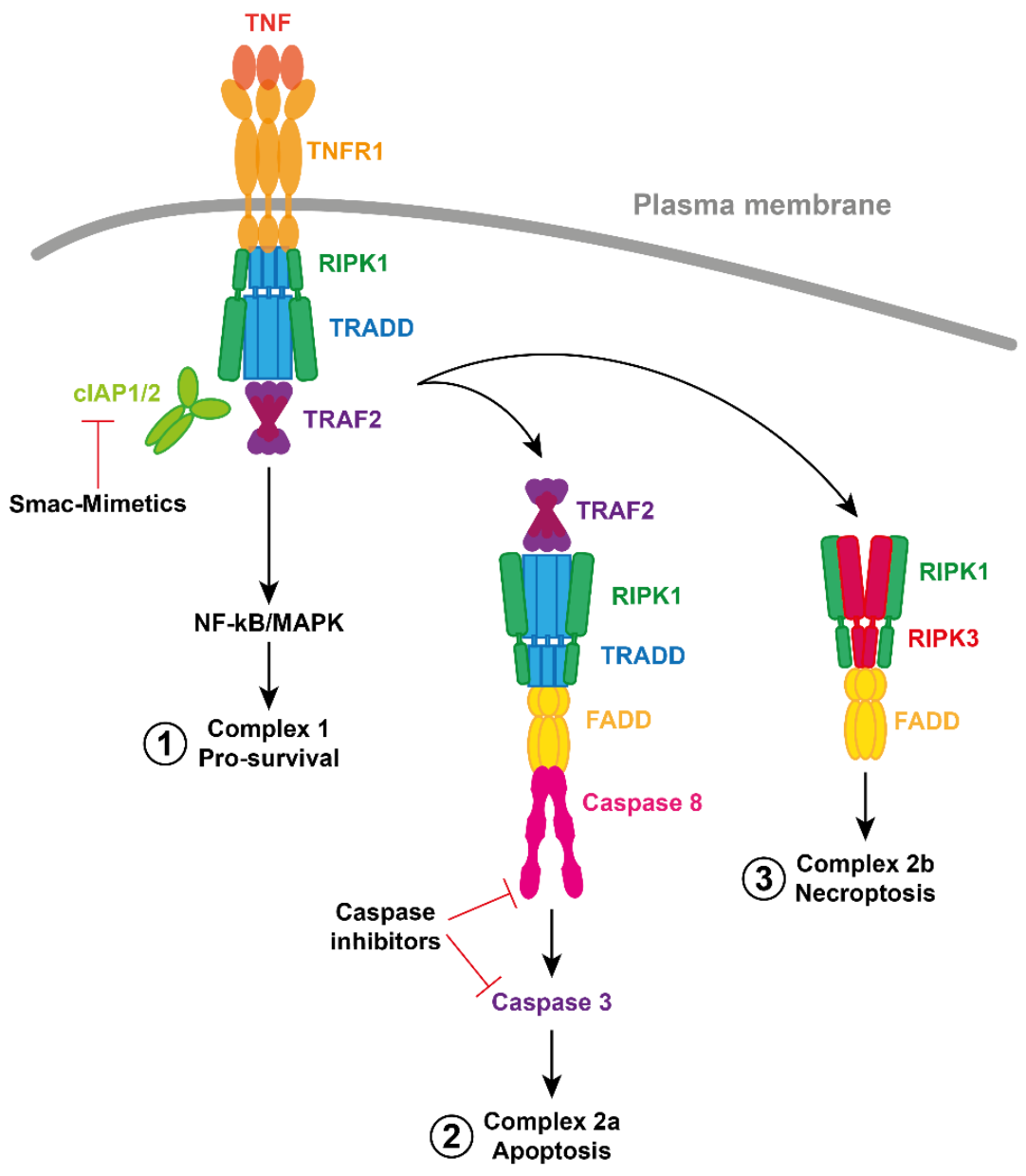

Figure 2. Simplified schematic of TNFR1 Signaling. Formation of complex 1 can lead to activation of canonical NF- $\mathrm{KB}$ and MAPK pro-survival signaling. Antagonism (or loss) of cIAP proteins induced by Smac-Mimetics leads to formation of complex 2a, containing TRADD, RIPK1, FADD and caspase-8. Caspase- 8 activation and cleavage, and activation of caspase- 3 , results in apoptosis. Alternatively, if caspases are inhibited, complex $2 \mathrm{~b}$ can form via a RHIM motif dependent recruitment of RIPK3. RIPK3 auto-phosphorylates and phosphorylates the pseudokinase MLKL. Phosphorylation of MLKL leads to a conformational change, membrane translocation, oligomerization, membrane permeabilization and necroptotic cell death.

\section{Development of Smac-Mimetics}

Overexpression of IAPs has been associated with multiple cancers, including hematological and solid cancers, and is indicative of poor prognosis [27,50,51]. Clinically, it was observed that patients expressing higher levels of Smac had a more favorable prognosis, with higher remission rates and longer overall survival [27]. Proof of principle for targeting IAPs was provided by the demonstration that exogenously expressing Smac in resistant neuroblastoma cells sensitized them to TNF-Related Apoptosis-Inducing Ligand (TRAIL) induced apoptosis [52]. Subsequent studies using antisense oligonucleotides against XIAP or synthetic Smac peptides, showed that these also sensitized cancer cells to chemotherapy [53,54]. Together, with other studies, this prompted the pharmaceutical development of small molecule, peptide-like mimetics of Smac, termed Smac-Mimetics (SMs). SMs mimic the minimal $\mathrm{N}$-terminal tetrapeptide $\left(\mathrm{NH}_{2}\right.$-AVPI), that constitutes a significant part of the IBM, which binds to the BIR domains of CIAP1/2 and XIAP $[35,55,56]$. Many of these mimetic compounds have shown anti-cancer effects in vitro and in vivo, validating the development of clinical SMs [27,57-60].

Endogenous Smac homodimerizes through an extensive hydrophobic interface and is bivalent [61]. Potent and selective bivalent SMs, as well as monovalent compounds, have been developed for the 
clinic. Monovalent SMs have one AVPI-like binding motif whilst bivalent SMs have two. To date, five monovalent compounds, GDC-0152, CUDC-427 (GDC-0917), Debio 1143 (AT-406), LCL161 and BI 891065, and three bivalent compounds, birinapant (TL32711), APG-1387, HGS1029 (AEG40826), have entered clinical trials for the treatment of cancer (Figure 3).

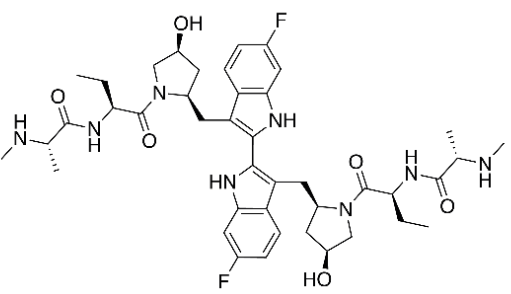

Birinapant (TL32711)

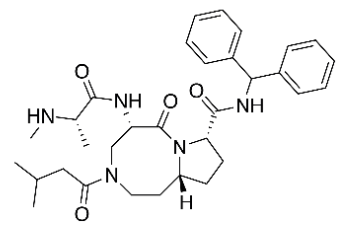

Debio 1143 (AT-406)

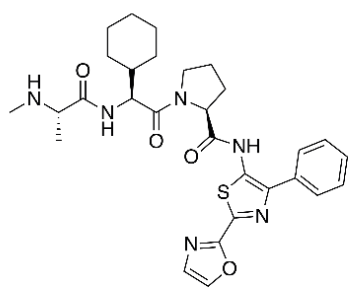

CUDC-427 (GDC-0917)
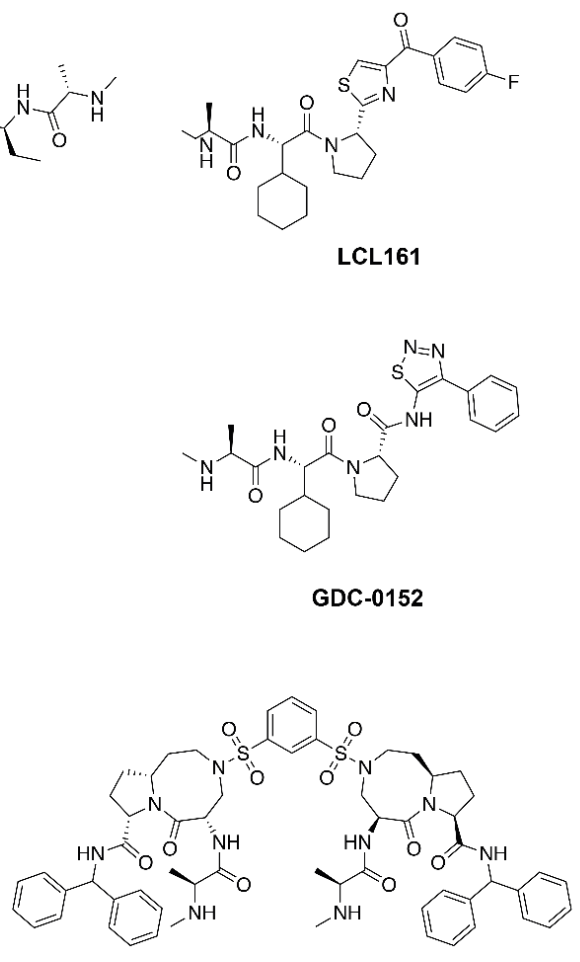

APG-1387

Figure 3. Structures of Smac-Mimetic compounds that have progressed to clinical trials. Note, the structures of HGS1029 (AEG40826) and BI 891065 are not publicly available.

\section{Smac-Mimetics as Single Agents in Pre-Clinical and Clinical Studies}

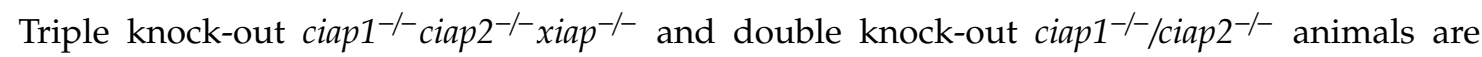
embryonic lethal. In contrast, double knock-out ciap $2^{-/} / x i a p^{-/}$are viable [62]. There are two conflicting reports with regard to $\mathrm{ciap}^{-1-} / \mathrm{xiap}^{-/-}$with one strain being embryonic lethal [62] and another viable [63]. At the least, these data suggest that inhibiting all three anti-apoptotic IAPs may be undesirable from a safety perspective. Certainly SMs that inhibit all three with low nanomolar $K_{\mathrm{i}}$ tend to have a more inflammatory profile and be more toxic to cells than ones with a more restricted profile (Table 1) [50,64-66].

Table 1. $K_{\mathrm{i}}(\mathrm{nM})$ values for clinically relevant Smac-Mimetic compounds.

\begin{tabular}{cccccc}
\hline Smac-Mimetic & cIAP1 & cIAP2 & XIAP & ML-IAP & Reference \\
\hline Birinapant & $\sim 1$ & 36 & $50 \pm 23$ & $\sim 1$ & Condon et al., 2014 \\
LCL161 & - & - & - & - & Derakhshan et al., 2016 \\
Debio 1143 & 1.9 & 5.1 & 66.4 & - & Cai et al., 2011 \\
GDC-0152 & 17 & 43 & 28 & 14 & Flygare et al., 2013 \\
CUDC-427 & $<60$ & $<60$ & $<60$ & $<60$ & Wong et al., 2013 \\
\hline
\end{tabular}




\subsection{Birinapant}

Birinapant (previously known as TL32711, Tetralogic Pharmaceuticals) is one of the most clinically progressed SMs [50]. Birinapant's higher affinity for the BIR3 of cIAP1 $\left(K_{\mathrm{i}} \sim 1 \mathrm{nM}\right)$ than for that of cIAP2 (36 nM) and XIAP $(50 \pm 23 \mathrm{nM})$ is likely to contribute to its good safety profile $[50,62]$. Birinapant's anti-cancer activity as a single agent has been extensively investigated in vitro and in vivo. Benetatos et al., undertook a large-scale screen in vitro of 111 different malignancies and observed 18 $(16 \%)$ were sensitive to birinapant single-agent treatment [67]. Interestingly, single-agent birinapant treatment in vivo in 50 patient-derived xenotransplant models of ovarian, colorectal and melanoma cancer, resulted in inhibition of tumor growth in roughly one third [67]. Similarly, although the human melanoma cell lines $451 \mathrm{Lu}$ and $1025 \mathrm{Lu}$ were both resistant to birinapant in vitro, in xenotransplantation models of these cells, treatment with birinapant single agent led to significant slowing of tumor growth for both cell lines [68]. It is possible that this unexpected improvement of efficacy in vivo compared with in vitro, is due to elevated levels of TNF in the microenvironment of melanoma lesions due to chronic inflammation [69]. While TNF has pro-survival effects on melanoma cells, enhancing invasion and migration potential [70], SMs can convert this advantage to a liability. These results highlight that SMs may synergize with an inflammatory environment, whether induced or otherwise, to cause cancer cell death [71-73].

A recent analysis of 279 Head and Neck Squamous Cell Carcinoma (HNSCC) tumors by The Cancer Genome Atlas (TCGA) identified roughly thirty percent of HNSCC patients have genomic amplifications of Fas-Associated Death Domain $(F A D D)$, with a subset of these patients also having amplifications in BIRC2/CIAP1 or BIRC3/CIAP2 [74,75]. Birinapant was effective as a single agent both in vitro and in vivo in HNSCC cells overexpressing FADD, with differential expression levels of cIAP1. Interestingly, following overexpression of FADD in the FADD-deficient cell line UM-SCC-38, birinapant treatments were effective at inducing cell death, implicating FADD as an important component in SM mediated killing [74,76]. In Inflammatory Breast Cancer (IBC), overexpression of XIAP has been correlated with acquired therapeutic resistance to apoptotic stimulus such as TRAIL [77]. Single-agent treatment with birinapant in TRAIL resistant IBC cell lines was pro-apoptotic, leading to cell death [78]. The authors proposed that this sensitivity was due to birinapant's activity towards XIAP, as a related bivalent SM that binds XIAP less potently $\left(K_{d} 0.45\right.$ and $>1 \mu \mathrm{M}$ respectively) was not as effective at inducing cell death [78]. However, caveats to this conclusion are that cIAP2 binding was not examined and the different physico-chemical properties of the two compounds was not discussed [78].

The first in-human clinical trial with birinapant was in patients with advanced solid tumors or lymphoma (NCT00993239). Birinapant was administered intravenously, with a dose-escalation from 0.18 to $63 \mathrm{mg} / \mathrm{m}^{2}$, once a week, every three out of four weeks. The Maximum Tolerated Dose (MTD) was determined as $47 \mathrm{mg} / \mathrm{m}^{2}$, with the maximum dose $63 \mathrm{mg} / \mathrm{m}^{2}$ having Adverse Effects (AEs) including headache, nausea and vomiting. Intriguingly, 2 out of 3 patients receiving $63 \mathrm{mg} / \mathrm{m}^{2}$ presented with Bell's palsy, a facial nerve paralysis [79]. Although birinapant accumulated in tumor tissue and had on target effects as an IAP inhibitor, no Complete (CR) or Partial Responses (PR) were observed in the 26 patients who were eligible for evaluation. Stable disease was observed in 7 patients $(27 \%)$ and 2 patients with colorectal cancer demonstrated radiographic evidence of tumor shrinkage [79]. A second Phase I/II clinical trial with birinapant was conducted in patients with relapsed Acute Myeloid Leukemia (AML) or MyeloDysplastic Syndrome (MDS). Birinapant was administered at varying doses $\left(17,22\right.$ or $\left.26 \mathrm{mg} / \mathrm{m}^{2}\right)$ and frequency (weekly, twice weekly or three times weekly) [80]. One case of Bell's palsy was observed at $22 \mathrm{mg} / \mathrm{m}^{2}$ dosed twice a week, and the three times a week dosing schedule was abandoned due to feasibility concerns. Best responses included a reduction in bone marrow blasts from $60 \%$ to $10 \%$ [80]. A Phase II single-agent trial of birinapant in 11 patients with relapsed platinum-resistant or -refractory epithelial ovarian cancer was conducted using the pre-established MTD of $47 \mathrm{mg} / \mathrm{m}^{2}$, administered once a week, three out of four weeks (NCT01681368) [79,81]. Similar to previous studies, birinapant demonstrated potent on target inhibition of IAPs, but no clinical benefit was observed, and therefore the study was terminated [81]. Together, these first in-human studies with 
birinapant indicate that as a single agent, birinapant has some anti-cancer activity but is unlikely to be universally effective in treating cancer. Despite the incidences of Bell's palsy (which is reversible upon birinapant reduction or withdrawal), the good tolerability profile of birinapant suggests that it has the potential to be combined with chemotherapy and TNF enhancing therapy.

\subsection{LCL161}

LCL161 (Novartis) is a structural analogue of the SM compound LBW242 and has also progressed into the clinic $[82,83]$. It is an orally available monovalent compound that inhibits multiple IAPs including XIAP, cIAP1 and cIAP2 [82-84]. $K_{\mathrm{i}}$ values for individual IAPs do not appear to have been published for this compound. However, like birinapant, it promotes degradation of cIAP1 and appears to have greater activity against cIAP1 and CIAP2 than XIAP [85]. Initial studies with LCL161 showed its efficacy as a single agent towards mutant FLT3- and BCR-ABL-positive leukemia cells [82]. In human HepatoCellular Carcinoma (HCC) cell lines Hep3B and PLC5, LCL161 had single-agent activity ( $\mathrm{IC}_{50} 10.23$ and $19.19 \mu \mathrm{M}$ respectively) and induced cell death [86]. Further studies have also identified LCL161 single-agent activity in Multiple Myeloma (MM) in vitro and in vivo [72,87]. Although there was a mixed anti-tumor response in LCL161 treated MM cell lines, degradation of cIAP1 and inhibition of XIAP was observed in all cells tested [87]. In the study by Chesi et al., MM cells were resistant in vitro to LCL161 except at doses that were not clinically achievable [72]. Other studies have also reported differential responses of tumors to LCL161 treatment. In particular the Pediatric Preclinical Testing Program (PPTP) screened 23 cell lines in vitro and 46 xenograft models in vivo and reported a variable and limited response to LCL161 within these childhood cancer cell lines [88]. The relationship between TNF expression and treatment sensitivity of PPTP cell lines was investigated by the authors [89]. Although two of the most sensitive tumors (anaplastic large cell lymphoma Karpas-299 cell line and medulloblastoma BT-39 xenograft) showed elevated TNF expression, multiple B-precursor Acute Lymphoblastic Leukemia (ALL) xenografts, which also presented with moderate levels of TNF, were resistant to LCL161 treatment [88]. In a later study, Faye and colleagues identified the dependence of RhabdoMyoSarcoma (RMS) tumors on cIAP1 and observed that LCL161 treatment of mice with established Kym-1 RMS xenograft tumors led to tumor cell death and prolonged survival (mean survival days were 46 vs. $77.69 \pm$ SEM) [90]. Strikingly, if LCL161 treatment was initiated prior to tumor growth, mice did not develop tumors by 120 days, effectively preventing the establishment of disease [90]. However, it should be noted that Kym-1 cells are exquisitely sensitive to SM treatment [20], for example compound A (a preclinical precursor of birinapant) has an $\mathrm{IC}_{50}$ of $\sim 50$ pmol (unpublished).

The first in-human clinical trial of LCL161 tested the safety and effectiveness of the SM in patients with advanced solid tumors (NCT01098838). After treating 53 patients with a dose range of 10 to $3000 \mathrm{mg}$ of LCL161, the MTD was determined as $1800 \mathrm{mg}$, administered orally once a week. Higher doses led to AEs of cytokine release syndrome, vomiting, nausea, fatigue and anorexia. No patients had an objective response, with 19\% having a best response of stable disease [91]. Degradation of cIAP1 and increased circulating cytokine levels, including TNF, were observed in patients dosed with lower concentrations than the MTD, indicating that the dosage of $1800 \mathrm{mg}$ is sufficient to target IAPs irrespective of individual patient pharmacokinetics. As observed in in vitro testing of cancer cell lines, the lack of efficacy of LCL161 in this study correlated with lack of basal production and insensitivity of tumor cells to TNF. Therefore, future studies with LCL161 should focus on the screening of patients that express and are sensitive to TNF [91].

\subsection{Debio 1143}

Debio 1143 (also known as AT-406) is a monovalent SM that was first described in 2011 and developed by Ascenta Therapeutics. This compound has oral bioavailability and targets cIAP1 $>$ cIAP2 $>$ XIAP with $K_{\mathrm{i}}$ values of 1.9, 5.1 and $66.4 \mathrm{nM}$ respectively [92]. Initial studies evaluated its single-agent capacity to inhibit cancer cell growth in vitro in more than 100 human cancer cell lines and observed that $15 \%$ were sensitive. As a single agent, Debio 1143 inhibited tumor growth in MDA-MB-231 breast 
cancer xenograft models [92]. Further analysis of Debio 1143 showed it also had single-agent activity in $60 \%$ of ovarian cancer cell lines tested in vitro. Intriguingly, 3 out of 5 carboplatin resistant ovarian cell lines were sensitive to single-agent treatment. This finding highlights the ability of SMs to drive cell death through molecular mechanisms independent of classical chemotherapy [93].

Analysis of a mouse xenograft model treated with Debio 1143 showed it was quickly absorbed and distributed after oral administration, and in the lung, blood, kidney and liver it reached maximum serum concentration within 15 min [94]. Debio 1143 progressed into first-in-human Phase I clinical trials in patients with advanced metastatic solid cancer (30 patients) and lymphoma (1 patient) (NCT01078649) [95]. Debio 1143 was administered orally at a dose range of 5 to $900 \mathrm{mg}$, daily from days 1 to 5, then every 14 days and then later every 21 days. A MTD was not confirmed and AEs experienced included fatigue, nausea and vomiting, with 4 patients withdrawing from the trial [95]. As with birinapant and LCL161, on target activity was seen, with rapid degradation of cIAP1 in tumor tissue and no CRs or PRs were observed. Stable disease as best response was seen in 5 patients. The authors of the study highlight the need for combination approaches and screening of sensitive markers for the clinical progression of IAP inhibitors [95].

\subsection{GDC Smac-Mimetics}

Compounds by Genentech, GDC-0152 and CUDC-427 (also known as GDC-0917 and currently being developed by Curis) were reported in 2012 and 2013 respectively. Both are pan-selective IAP antagonists with $K_{i}$ values towards cIAP1, cIAP2, XIAP and ML-IAP less than 60 nM [96,97]. The advantage of CUDC-427 over GDC-0152 is its increased oral bioavailability [97].

Initial studies with single treatment of both compounds demonstrated safety towards healthy mammary epithelial tissue and efficacy in inhibiting tumor growth in MDA-MB-231 breast cancer xenograft models [96,97]. Tchoghandjian and colleagues showed that glioblastoma cell lines and primary human samples all expressed IAP proteins, cIAP1/2, XIAP and ML-IAP, albeit at varying levels [98]. Intriguingly, analysis of two cohorts, totaling 101 primary human glioblastoma samples, indicated that high expression levels of ML-IAP were indicative of worse progression-free and overall survival [98]. Therefore, the authors chose to test the ability of GDC-0152, a SM with high affinity towards ML-IAP, to induce glioblastoma cell death in vitro and in vivo. In vitro treatment with GDC-0152 decreased the expression levels of IAP proteins, including ML-IAP in three out of four glioblastoma cell lines, driving apoptotic cell death. In vivo studies using the sensitive U87MG glioblastoma cell line orthotopically xenografted into mice, showed that GDC-0152 postponed tumor development and increased survival [98]. The fact that GDC-0152 and CUDC-427 potently target ML-IAP indicates that they may offer benefit to patients suffering from cancer where ML-IAP is a biomarker of poor prognosis.

The progression of GDC-0152 and CUDC-427 into human clinical trials followed positive preclinical modelling and simulation exercises to predict in-human safety [97]. Although initial data showed GDC-0152 was tolerated, translation of GDC-0152 into additional human clinical trials has been delayed due to withdrawal of a Phase I trial for reasons unrelated to safety or anti-tumor activity (NCT00977067). Similar to GDC-0152, CUDC-427's progression in human clinical trials has also been arrested. CUDC-427 was tested in a Phase I trial in 42 patients with advanced solid malignancies to determine its safety profile (NCT01226277) [99]. Patients were treated for two out of three weeks with escalating doses of CUDC-427, starting from $5 \mathrm{mg}$ and advancing to $600 \mathrm{mg}$. AEs included fatigue, nausea, vomiting and rash, with treatment being discontinued in six patients due to dose limiting toxicities. Although out of the 36 patients evaluable for response, 34 had no objective response, two patients (Mucosa-Associated Lymphoid Tissue (MALT) lymphoma of the stomach and the other a BRCA1 (germline) and platinum-refractory ovarian cancer) showed evidence of a durable CR [99]. The profound response experienced by these two patients warrants further investigation into patient indications to select sensitive candidates. Despite the initial promising results, progression of GDC SMs has halted following a second Phase I trial with CUDC-427 that was discontinued (NCT01908413) [99]. 


\subsection{Other Smac-Mimetic Drugs}

Numerous other SMs have been developed and undergone pre-clinical assessment. These include APG-1387, HGS1029 (also known as AEG40826) and BI 891065 (also known as BI5).

APG-1387 (Ascentage Pharma) has shown anti-cancer effects as a single agent in vitro and in vivo in nasopharyngeal carcinoma cells and in ovarian cancer cells [100-102]. APG-1387 is currently in dose-escalation Phase I/II clinical trials to determine safety, tolerability, pharmacokinetics and anti-cancer activity in patients with advanced solid tumors or hematological malignancies (Table 2) (NCT03386526, ACTRN12614000268640 and CTR20150161) [103,104].

HGS1029 (also known as AEG40826) was developed by Aegera Therapeutics Inc. and subsequently licensed to Human Genome Sciences Inc. for commercial development. Preliminary in vitro studies with HGS1029 have shown it has modest activity as a single agent in four out of eight pancreatic cancer cell lines tested [105]. The safety and efficacy of HGS1029 was assessed in a Phase I clinical trial in 44 patients with advanced solid tumors (NCT00708006). The most common AEs were nausea, anorexia, pyrexia, vomiting, diarrhea, fatigue and rash, with dose limiting toxicities being observed in one out of nine patients at $1.4 \mathrm{mg} / \mathrm{m}^{2}$ and in two out of six patients at $4.8 \mathrm{mg} / \mathrm{m}^{2}$. Best responses were one colon cancer patient presenting with tumor regression and two patients, with Non-Small-Cell Lung Carcinoma (NSCLC) and adrenocortical carcinoma, having stable disease for more than 6 months [106,107]. Despite these promising results, progression of HGS1029 has been attenuated due to termination of a second Phase I clinical trial (NCT01013818).

BI 891065 (also known as BI5) was developed by Boehringer Ingelheim and has higher selectivity towards cIAP1 and cIAP2 compared to XIAP. BI 891065 has shown modest single-agent efficacy in MBT-2 bladder cancer and EMT6 breast cancer cell lines [108]. It is currently in human clinical Phase I trials to determine safety, tolerability and efficacy (Table 2) (NCT03697304, NCT03166631 and NCT04138823).

Table 2. In progress clinical Smac-Mimetic trials.

\begin{tabular}{|c|c|c|c|c|c|}
\hline Smac-Mimetic & Adjuvant Therapy & Cancer & Phase & Clinical Trial & Date \\
\hline Birinapant & Pembrolizumab & Solid cancer & $\mathrm{I} / \mathrm{II}$ & NCT02587962 & Aug-17 \\
\hline Birinapant & Radiation & HNSCC & $\mathrm{I}$ & NCT03803774 & Jan-19 \\
\hline LCL161 & None & Myelofibrosis & II & NCT02098161 & Dec-14 \\
\hline LCL161 & Immunotherapy $^{\mathrm{a}}$ & Solid tumors ${ }^{b}$ & $\mathrm{Ib}$ & NCT02890069 & Oct-16 \\
\hline LCL161 & Immunotherapy ${ }^{c}$ & Multiple myeloma & I & NCT03111992 & Dec-17 \\
\hline LCL161 & Topotecan & Solid tumors ${ }^{d}$ & $\mathrm{I} / \mathrm{II}$ & NCT02649673 & Mar-16 \\
\hline Debio 1143 & Nivolumab & Solid cancer & $\mathrm{I} / \mathrm{II}$ & NCT04122625 & Apr-19 \\
\hline Debio 1143 & Pembrolizumab & Solid tumors ${ }^{\mathrm{e}}$ & $\mathrm{I}$ & NCT03871959 & Sep-19 \\
\hline Debio 1143 & Avelumab & NSCLC & $\mathrm{Ib}$ & NCT03270176 & Oct-17 \\
\hline Debio 1143 & Cisplatin/radiotherapy & HNSCC & $\mathrm{I} / \mathrm{II}$ & NCT02022098 & Oct-13 \\
\hline APG-1387 & None & Solid cancer/Hema & $\mathrm{I} / \mathrm{II}$ & NCT03386526 & Nov-17 \\
\hline BI 891065 & Immunotherapy ${ }^{\mathrm{f}}$ & Solid tumors $\mathrm{g}$ & $\mathrm{I}$ & NCT03166631 & Sep-17 \\
\hline BI 891065 & Immunotherapy ${ }^{\mathrm{f}}$ & Neoplasm metastasis & II & NCT03697304 & Mar-19 \\
\hline BI 891065 & Immunotherapy $\mathrm{f}$ & Neoplasm & I & NCT04138823 & Nov-19 \\
\hline
\end{tabular}

${ }^{a}$ PDR001 checkpoint inhibitor. ${ }^{b}$ Colorectal cancer, non-small cell lung carcinoma (NSCLC), triple negative breast cancer, renal cell carcinoma. ${ }^{\mathrm{c}}$ PDR001, anti-IL-17 monoclonal antibody CJM112. ${ }^{\mathrm{d}}$ Small cell lung cancer, ovarian cancer. e Adenocarcinoma of the pancreas, colon and rectum. ${ }^{\mathrm{f}}$ anti-PD-1 monoclonal antibody BI 754091. $\mathrm{g}$ Neoplasms, neoplasm metastasis, NSCLC.

\section{Mechanisms of Resistance to Smac-Mimetics and Strategies to Overcome Them}

The Phase I/II human clinical trials of SMs indicated they are tolerated as single agents but have low efficacy. Therefore, pre-clinical and clinical research has been conducted to identify biomarkers of response and combination treatments that can increase the effectiveness of SM treatment. 


\subsection{Importance of TNF}

The ability of a tumor to produce and respond to TNF (or another TNFSF death ligand) is vital for the anti-tumor effect of SMs, and tumors that lack either of these functions will most likely be resistant to SM treatment $[17,20,109,110]$. For this reason, an obvious initial combination therapy was the addition of exogenous TNF (or TRAIL) to overcome SM treatment resistance. The efficacy of TNF and/or TRAIL in combination with birinapant is demonstrated by the sensitization of 41 out of 93 birinapant resistant malignancies in vitro [67]. In HNSCC cell lines with differential expression of FADD and cIAP1, addition of TNF or TRAIL dramatically sensitized all tumors to birinapant-mediated killing [76]. Similar results have also been observed in melanoma cell lines where 9 out of 16 birinapant resistant tumors were dramatically sensitized to birinapant-mediated killing with the addition of TNF [68].

Despite these results indicating addition of exogenous TNF in vitro is able to sensitize SM resistant tumors to treatment, administrating TNF systemically to patients is not feasible due to extreme toxicities observed at therapeutically relevant doses [111]. Isolated Limb Perfusion (ILP) is one technique that has been used to administer TNF at therapeutically relevant doses in combination with chemotherapies. However, the technical challenges and innate limitations of ILP means it is only plausible for a minority of localized cancers and therefore alternative methods have been developed to be used in combination with SMs [112]. For example, to overcome the barrier of systemically safe, tumor specific TNF delivery, Yuan and colleagues developed a novel system whereby systemic delivery of Adeno-Associated Virus bacterioPhage-TNF (AAVP-TNF) enables tumor vasculature-targeted gene therapy [113]. This system allows delivery of TNF directly to the tumor tissue, minimizing systemic toxicity [113-115]. Co-administration of AAVP-TNF and LCL161 to M21 human xenograft mice led to increased expression of TNF specifically in tumor tissue, and not in healthy organs. Combination therapy was synergistic and significantly prolonged survival of mice [113]. Similarly, cytokine-engineered oncolytic viruses, such as the TNF-armed attenuated oncolytic Vesicular Stomatitis Virus (VSVA51), combined with the SM LCL161, slowed tumor growth and improved survival rates in mouse models of solid tumors [116]. These findings support the hypothesis that increasing TNF expression in vivo potentiates SM treatment.

Another approach has been to enhance the levels of TNF expressed by the tumor, by targeting parallel signaling pathways. A boutique screen of kinase inhibitors in macrophages showed, surprisingly, that 11 distinct p38 MAPK inhibitors synergized with compound A, the preclinical precursor of birinapant, to increase TNF production and macrophage killing [117]. One of these, LY2228820 (Ralimetinib), was shown to increase induction of TNF by SM treatment leading to synergistic potentiation of birinapant killing of AML cells both in vitro and in vivo [117]. Another approach has been to induce TNF in tumors more conventionally using Toll-Like Receptor (TLR) ligands, such as CpG and poly(I:C). Surprisingly, when combined with LCL161 in an in vivo model, peritoneal injection of poly(I:C) was better at curing the mice than intra-tumoral injection. However, when combined with $\mathrm{CpG}$, the best responses were dual intra-tumoral and peritoneal injections [71]. These results certainly suggest that SMs can combine with circulating TNF and not just TNF produced in the tumor micro-environment.

\subsection{Combination with Radiation}

Having established the neccessicity of TNF for SM-mediated killing, and the potential for increased TNF to overcome treatment resistance, novel combination therapies were explored that combined SMs with TNF enhancing therapy. Hallahan and colleagues reported that treatment of human sarcoma cells with ionizing radiation led to an increase in TNF mRNA and an increased production of TNF protein. The increased production of TNF enhanced radiation-mediated killing through autocrine and paracrine mechanisms [118]. Armed with this knowledge, the combination of SMs with radiation was explored to overcome TNF-mediated SM resistance in cancer. Birinapant or radiation single-agent treatment only modestly extended the survival of mice burdened with FADD overexpressing HNSCC UM-SCC-46 
xenograft tumors [74]. Strikingly, however, the combination of SM with radiation cured these mice of HNSCC tumors with no signs of relapse, up to 130 days [74]. A potent increase in endogenous TNF levels in the tumors was found, corroborating the hypothesis that the radiosensitization effect of birinapant is due to an enhancement of TNF in the environment. Similar findings were observed in Esophageal Squamous Carcinoma (ESCC) cells, where the radiosensitizing effect of LCL161 was investigated. ESCC cells were differentially sensitive to SM single-agent treatment. However, addition of radiation increased radiation-induced TNF, DNA fragmentation and apoptosis of these cells. The pan-caspase inhibitor zVAD-FMK attenuated apoptosis, therefore the sensitization mediated by the addition of LCL161 was due to the activation of the TNFR1 extrinsic apoptotic pathway [119]. Further studies showed that Debio 1143 significantly enhanced radiosensitization in NSCLC and HNSCC tumors in vitro and in vivo [120,121]. This sensitization was driven by an increase in autocrine TNF production and cell death was mediated by caspases [120,121]. Due to these promising findings, radiation therapy is being trialed in HNSCC tumors in combination with birinapant (NCT03803774) and Debio 1143 (NCT02022098).

\subsection{Combination with Chemotherapy}

Upon exposure of cells to cytotoxic drugs and DNA-damaging agents, a measurable decrease in endogenous Smac within the mitochondria and an accumulation within the cytosol can be observed [122]. Therefore, SMs provide a means to augment the natural response to cytotoxic compounds. Chemotherapy remains the front-line treatment for a range of cancers, rationalizing the exploration of pairing SMs with chemotherapies for combination treatment. Paclitaxel is one of the first-line chemotherapy treatments for NSCLC. However, due to its limited efficacy in some patients, new combination treatments are being investigated [123]. An increase in expression of cIAP levels has been shown to correlate with poor prognosis and lower overall survival in various types of cancer, including NSCLC [124-127]. Therefore, combining the SM LCL161 with paclitaxel in NSCLC tumors was investigated. Addition of LCL161 to paclitaxel therapy increased TNF expression, degradation of cIAP1/2 and activation of caspase-8 dependent apoptotic signaling, sensitizing NSCLC cancer cells to treatment in vitro [124]. Similar findings were observed in mice xenografted with NSCLC tumors where LCL161 plus paclitaxel treatment had better anti-tumor activity than either treatment alone [124].

Treatment of HNSCC cell lines with birinapant plus docetaxel was more effective than either treatment alone in vitro [76]. However, while birinapant plus docetaxel treatment of mice burdened with HNSCC xenografts significantly reduced tumor volume, there was no extension in survival compared to control treated mice [76]. Surprisingly, however, there was a significant extension in survival with birinapant single-agent treatment, although it was less effective at reducing tumor volume [76]. The authors suggested that a different dosing schedule might have increased survival in the combination treated animals, but regardless, the results yet again emphasize that in vivo response to birinapant can be better than predicted from in vitro studies. In HL-60, OVCAR-3 and HT-1376 cancer cell lines, the effects of birinapant treatment could be enhanced by the addition of chemotherapy agents SN-38 (active metabolite of irinotecan), gemcitabine or 5-azacytidine, but not pemetrexed, vemurafenib, bendamustine or sorafenib [67]. Interestingly, in the HT-1376 bladder cancer cell line, the potentiation of birinapant and gemcitabine treatment was not attenuated by co-treatment with an anti-TNF antibody, thus indicating that the increase in cell death was via a TNF-independent-mechanism in this tumor [67].

Platinum-based chemotherapy, commonly carboplatin, is the front-line therapy for ovarian cancer patients. However, patients can develop resistance to treatment [128,129]. In High-Grade Serous ovarian Cancer (HGSC) primary samples, a small proportion of cells were platinum resistant and possessed stem cell characteristics of tumor initiation, multi lineage differentiation, self-renewal and had high expression of IAP proteins. Co-treatment of birinapant with carboplatin led to sensitization of these cells and increased killing in a caspase- 8 dependent mechanism in vitro and in xenograft HGSC models [130]. As expected, Human Ovarian AdenoCarcinoma (HOAC) cells had a variable response to carboplatin single-agent treatment, with three out of five being resistant. However, despite 
resistance to chemotherapy, co-treatment with Debio 1143 with carboplatin sensitized these cells to cell death in vitro [131]. Treatment of carboplatin and Debio 1143 in vitro resistant SKOV-3 HOAC xenograft burdened mice with carboplatin had no effect, whilst treatment with Debio 1143 single agent induced a slow-down in tumor growth and complete regression in one out of seven mice. This effect was potentiated with the addition of carboplatin leading to slow-down of tumor growth in two mice and complete regression in five mice (out of seven) [131]. Furthermore, in vivo treatment of OVCAR3ip (cells selected in vivo from OVCAR3 parental cells to form ascites) carboplatin-resistant ovarian xenograft models with Debio 1143 in combination with carboplatin was able to prolong survival of mice better than single treatments [93]. The capacity of SMs to act as single agents or in combination with carboplatin to kill carboplatin resistant ovarian cancer cell lines validates them as a combination or alternative therapy to overcome resistance [93].

The preclinical data discussed above indicated SMs are more efficacious when combined with TNF inducing chemotherapies than alone. For this reason, birinapant was combined with several chemotherapies including, carboplatin/paclitaxel, irinotecan, docetaxel, gemcitabine or liposomal doxorubicin for the treatment of patients with solid tumors. Co-treatment of birinapant with these diverse chemotherapies in 124 patients with refractory/relapsed solid tumors did not limit the dose of chemotherapy administered. Despite seven patients experiencing reversible Bell's palsy symptoms, overall birinapant was well tolerated in combination with chemotherapy as a treatment. Clinical benefit was observed in numerous patients, with 11 patients having a PR and 61 having stable disease. Of the chemotherapies tested, irinotecan enhanced birinapant's activity the most, even in patients that had previously failed irinotecan therapy (NCT01188499) [132]. Therefore, a Phase II extension study was conducted combining birinapant with irinotecan in irinotecan-relapsed or refractory metastatic ColoRectal Cancer (CRC) patients [133]. Birinapant was administered at a fixed dose or in an Ascending Dose Schedule (ADS) in combination with irinotecan at a fixed dose. The combination was well tolerated, and the ADS appeared to prevent symptoms of Bell's palsy. Two patients achieved a PR, while 27 had stable disease. Together, this study supports the idea that combining birinapant with the TNF inducing chemotherapy irinotecan may be a feasible therapeutic strategy for irinotecan resistant tumors (NCT01188499) [133].

As discussed above, the chemotherapy paclitaxel has been shown to potentiate LCL161 mediated killing in solid tumors, including Triple Negative Breast Cancer (TNBC) [124,134-136]. Phase II clinical trials were initiated [137], following Phase I trials that indicated that LCL161 plus paclitaxel therapy is well tolerated [134]. Interestingly, for this study the TNF-based Gene expression Signature (GS) was determined for each patient and used as a predictor of sensitivity to SM-mediated cell death [137]. Bardia and colleagues conducted a global trial incorporating molecular pre-screening to investigate the neoadjuvant treatment of LCL161 and paclitaxel in TNBC patients assigned as GS-positive (more likely to respond to SM treatment) vs. GS-negative (less likely to respond) [137]. Of 207 patients, $30.4 \%$ had a GS-positive score and combination treatment was more effective than paclitaxel alone treatment. However, in the GS-negative group comprising $69.6 \%$ of the patient population, there was an antagonistic effect in combination treatment compared to control arms. This study highlights the importance of molecular screening to determine eligibility of patients and the analysis of possible increased toxicities (NCT01617668) [137].

\subsection{Combination with Bcl-2 Inhibitors}

B-cell lymphoma 2 (Bcl-2) prevents Bax/Bak mediated disruption of the mitochondrial outer-membrane, preventing cell death and efflux of cytochrome $c$ from the mitochondrial inter-membrane space [138-140]. Efflux of endogenous Smac from within the mitochondria is also regulated by Bcl-2 and cells overexpressing Bcl-2 inhibit the release of Smac from the mitochondria following apoptotic stimulus [37,122]. Combining SMs with other specific inducers of cell death, such as Bcl-2 inhibitors, might increase efficacy and reduce toxicity. Preliminary studies where the authors knocked down Bcl-2 which led to resistant Huh7 cells becoming sensitized to LCL161 treatment 
in vitro, were nevertheless discouraging because the level of cell death achieved was minimal, less than $20 \%$ [86]. More impressive results were obtained combining the putative Bcl-2 inhibitor SC-2001 (a derivative of obatoclax) with LCL161 to treat Huh-7 xenograft tumors in vivo [86]. MM cells have been shown to have high expression of anti-apoptotic Bcl-2 family members [141,142] and IAP family members $[143,144]$, suggesting that the co-inhibition of these two families of proteins may be beneficial for the treatment of MM. Co-treatment with obatoclax and LCL161 led to a synergistic killing of MM cell lines [145]. However, this synergistic killing may not be due specifically to obatoclax inhibiting Bcl-2 because a number of well controlled studies have shown that obatoclax kills cells in a Bax-Bak independent manner and does not act as a BH3 mimetic [146,147]. A more recent study combining the specific Bcl-2 inhibitor ABT-199 with SMs birinapant or Debio 1143 showed an increase in human colon adenocarcinoma cell death compared to single-agent treatments [148]. Together, these preclinical studies indicate the potential for targeting the intrinsic and extrinsic apoptosis pathways in SM combination therapy.

\subsection{Combination with Immunotherapy}

Immunotherapy harnesses the immune system to kill tumors. Kearney et al. 2017 showed that the SM birinapant sensitized tumor cells to TNF dependent killing by Cytotoxic Lymphocytes (CLs), both CD8+ T cells and Natural Killer (NK) cells. Upon antigen recognition or NK-activating receptor activation, CLs naturally respond by inducing TNF. Surprisingly, given the data showing the ability of SMs to increase TNF levels, birinapant did not increase T-cell production of TNF [149]. On the other hand, tumor-derived Programmed Death-Ligand 1 (PD-L1) engagement of its receptor, Programmed cell Death protein 1 (PD-1), expressed on CLs, decreased CL production of TNF. Furthermore, while birinapant did not increase TNF secretion by CLs, it did sensitize the tumor cells to TNF induced death. Together, these results suggested that the combination of the Immune Checkpoint Inhibitor (ICI), anti-PD1, and birinapant would be a very effective way to increase CL killing. And indeed, this is what the authors observed [149]. Similarly, Beug and colleagues in an extensive and very detailed study, showed that combining the ICIs, anti-PD1 or anti-Cytotoxic T-Lymphocyte-Associated protein 4 (anti-CTLA-4), with the SM LCL161 greatly increased survival in intra-cranial mouse glioblastoma models and produced durable cures [150]. These results are particularly significant on several levels. Firstly, they show that the combination therapy works well in vivo without any reported toxicity. Secondly, the SM was delivered orally, yet the blood brain barrier, a significant barrier for many drugs, was not an impediment, and thus the combination works in one of the most challenging in vivo environments. Thirdly, the authors showed that more than one SM and ICI cocktail was effective, boosting confidence in the general utility of the approach. Lastly, the durable response was associated with immunological memory suggesting the potential of the therapy to deliver long-term cures. As in single-agent studies, TNF was an important part of the cytotoxic response and also required CD8+ T-cells [150]. Encouragingly, an independent study with the SM BI 891065 in combination with an anti-PD1 antibody also eradicated breast cancer tumors in immunocompetent mice [108].

Clinical trials in solid tumors with diverse SMs and immunotherapy are currently in progress; birinapant and Pembrolizumab (NCT02587962), LCL161 and PDR001 (NCT03111992 and NCT02890069), Debio 1143 and Nivolumab, Pembrolizumab or Avelumab (NCT04122625, NCT03871959 and NCT03270176), and BI 891065 and BI 754091 (NCT03697304, NCT03166631 and NCT04138823) (Table 2).

An alternative option to amplifying the immune response, is to reduce the threshold of a tumor cell to respond to immunotherapy. Using a CRISPR/Cas9 screen, Kearney et al. 2018, showed that the suppression of TNF, Interferon (IFN $\gamma$ ) and antigen presentation were key mechanisms by which tumors can evade the attack of CLs [151]. This matched well with previous clinical data showing that IFN $\gamma$ plays an important role in the efficacy of ICIs [152], but for the first time suggested TNF signaling was also an important component. They found that TNF was a potent NK cell effector molecule and that TNF-mediated apoptosis is important in a NK cell attack [151]. Subsequently, Vredevoogd and 
colleagues combined these earlier observations to show that increasing sensitivity of tumor cells to TNF killing by removal of TRAF2 enhanced the therapeutic effect of ICI drugs. And, as expected, given the important role TRAF2 plays in recruiting cIAPs and the synergistic effects of combining birinapant with ICIs in vitro shown by Kearney and colleagues, inhibition of cIAP1/2 by birinapant led to an even stronger response when combined with ICI drugs (anti-PD-1 therapy) [153]. Work showing that SMs can also synergize with Chimeric Antigen Receptor (CAR) T-cell therapy is discussed in an accompanying review in this series $[73,154]$.

\subsection{Inducing Necroptosis}

SMs can sensitize cells to both apoptotic and necroptotic cell death pathways mediated by TNFR1. As previously discussed, the majority of current cancer chemotherapies utilize the intrinisic apoptotic pathway to induce cell death. As many cancers have evolved resistance to cell death via apoptosis, the ability of SMs to regulate the TNF cell death pathways through promoting both apoptosis and necroptosis provides a promosing novel therapeutic avenue towards resistant malignancies $[155,156]$. Proof of principle for this concept has been shown as an effective way to kill AML cells both in vitro [157] and also safely in vivo [7]. Specifically Brumatti and colleagues induced necroptosis by combining birinapant with the U.S Food and Drug Administration (FDA) approved caspase inhibitor IDN-6556 (Emricasan) [7]. However, SM-mediated necroptotic cell death does not always require pharmaceutical inhibition of caspases. Birinapant has been observed to mediate cell death through dual action of apoptotic and necroptotic mechanisms in ALL [158]. Similarily, addition of Debio 1143 with the chemotherapy carboplatin led to ovarian cancer cell apoptotic or necroptotic cell death, depending on the cell line [131]. Reactive Oxygen Species (ROS) are volatile molecules and high levels can induce programmed cell death in their own right $[1,159]$. They have also been shown to influence cellular responses to TNF by regulating the NF- KB and apoptotic pathways [160]. In some cases, the presence of ROS has been shown to enhance both SM-mediated apoptotic and necroptotic cell death $[8,77,161]$. Taken together, these studies suggest that birinapant may possess a dual activity (apoptotic and non-apoptotic) in cancer cells, and that the ability to promote non-apoptotic cell death makes it an attractive drug for the treatment of apoptotic resistant cancers.

\subsection{Mechanical Resistance}

Recent studies have shown that SMs, including the clinically relevant birinapant, are substrates for the MultiDrug Resistance 1 (MDR1; gene name ABCB1) pump, also known as P-glycoprotein (P-gp) [162,163] (Morrish et al., unpublished). These transporters have been well characterized and their substrates are many. However, these recent studies identifying SMs as substrates have the potential to further inform future clinical trials in using patient MDR1 profiles for targeted therapy.

\section{Future Directions and Conclusions}

In this review, we have highlighted the progression of SMs from bench to bed-side. Eight compounds have been tested in humans, and all were well tolerated, had a reasonable safety profile, were shown to hit their target and displayed some anti-tumor activity. SMs are inherently non-toxic towards healthy tissue and the reason for this is not entirely understood. It has been proposed that because SMs are targeted drugs and specifically affect IAP signaling pathways, they have less toxicity than chemotherapies which alter many pathways [164-167]. Another explanation might be that abnormal expression of IAPs and/or TNF by the tumor or stromal cells in its environment leads to addiction to NF- $\mathrm{KB}$ and/or TNFR1 signaling pathways. Following the preliminary success of the SM compounds in vitro and in vivo, and their apparent low toxicity towards healthy tissue, they progressed into in-human clinical trials as single agents. However, a common draw back for all compounds is their limited clinical activity as single agents. Extensive investigation has been conducted over the last decade to enhance the efficacy of SMs as anti-cancer therapy. The strengths and weaknesses of SM therapy are complex and intertwined. TNF is an essential component for 
SM-mediated cell death. Tumors that do not produce and respond to TNF are inherently resistant to SM treatment, limiting therapy, but unfortunately it is not feasible to directly co-administer TNF to patients. Therefore, various combinations have been investigated to safely enhance the levels of TNF experienced by the tumor by targeting other signaling pathways, or using chemo-, radiation or immunotherapy. Alternative strategies to increase SM potential are through additional targeting of the intrinsic apoptosis pathway, activating the alternative cell death pathways such as necroptosis or preventing mechanical efflux of SM drugs. A common thread running through all these treatment options is that they will not work effectively in all patients, and thus the identification and validation of biomarkers of response are required to ensure that patients receive the most effective SM combination therapy. While there remains much work to be done, we believe the very specific action of SM drugs, with little evidence of off-target activity, the good safety profile (probably linked to specificity) and the potential to synergize with other equally exciting up-coming treatments, such as immunotherapy, augurs well for the clinical future of SMs.

Author Contributions: E.M. wrote the manuscript. G.B. and J.S. provided expert advice and edited the manuscript. All authors have read and agree to the published version of the manuscript.

Funding: This research was funded by a Leukemia \& Lymphoma Society SCOR (Specialized Centre of Research, grant \#7015-18 to J.S.), the National Health and Medical Research Council (NHMRC; grants 1025594, 1046010, and 1081376), a Cancer Australia and Leukaemia Foundation Australia priority grant (PdCCRS 1162023 to G.B.), NHMRC fellowship (1107149 to J.S.) and a Victoria Cancer Agency (VCA) mid-career fellowship (MCRF 15027 to G.B.). This work was made possible through the Australian Cancer Research Foundation and Victorian State Government Operational Infrastructure Support and Australian Government NHMRC IRIISS (9000433).

Acknowledgments: We thank Catia Pierotti for assisting with chemical structures. We apologize to all researchers in this field who were not cited due to space constraints.

Conflicts of Interest: The authors declare no conflict of interest.

\section{References}

1. Galluzzi, L.; Vitale, I.; Aaronson, S.A.; Abrams, J.M.; Adam, D.; Agostinis, P.; Alnemri, E.S.; Altucci, L.; Amelio, I.; Andrews, D.W.; et al. Molecular mechanisms of cell death: Recommendations of the Nomenclature Committee on Cell Death 2018. Cell Death Differ. 2018, 25, 486-541. [CrossRef]

2. Amaravadi, R.K.; Kimmelman, A.C.; Debnath, J. Targeting autophagy in cancer: Recent advances and future directions. Cancer Discov. 2019, 9, 1167-1181. [CrossRef] [PubMed]

3. Salvesen, G.S.; Duckett, C.S. Apoptosis: IAP proteins: Blocking the road to death's door. Nat. Rev. Mol. Cell Biol. 2002, 3, 401. [CrossRef] [PubMed]

4. Thornberry, N.A.; Lazebnik, Y. Caspases: Enemies within. Science 1998, 281, 1312-1316. [CrossRef] [PubMed]

5. Vandenabeele, P.; Galluzzi, L.; Vanden Berghe, T.; Kroemer, G. Molecular mechanisms of necroptosis: An ordered cellular explosion. Nat. Rev. Mol. Cell Biol. 2010, 11, 700-714. [CrossRef]

6. Edinger, A.L.; Thompson, C.B. Death by design: Apoptosis, necrosis and autophagy. Curr. Opin. Cell Biol. 2004, 16, 663-669. [CrossRef]

7. Brumatti, G.; Ma, C.; Lalaoui, N.; Nguyen, N.-Y.; Navarro, M.; Tanzer, M.C.; Richmond, J.; Ghisi, M.; Salmon, J.M.; Silke, N.; et al. The caspase-8 inhibitor emricasan combines with the SMAC mimetic birinapant to induce necroptosis and treat acute myeloid leukemia. Sci. Transl. Med. 2016, 8, 339-369. [CrossRef]

8. Schenk, B.; Fulda, S. Reactive oxygen species regulate Smac mimetic/TNF $\alpha$-induced necroptotic signaling and cell death. Oncogene 2015, 34, 5796. [CrossRef]

9. Silke, J.; Rickard, J.A.; Gerlic, M. The diverse role of RIP kinases in necroptosis and inflammation. Nat. Immunol. 2015, 16, 689. [CrossRef]

10. De Almagro, M.; Vucic, D. The inhibitor of apoptosis (IAP) proteins are critical regulators of signaling pathways and targets for anti-cancer therapy. Exp. Oncol. 2012, 34, 200-211.

11. Vaux, D.L.; Silke, J. IAPs, RINGs and ubiquitylation. Nat. Rev. Mol. Cell Biol. 2005, 6, 287. [CrossRef] [PubMed]

12. Obexer, P.; Ausserlechner, M.J. X-linked inhibitor of apoptosis protein-a critical death resistance regulator and therapeutic target for personalized cancer therapy. Front. Oncol. 2014, 4, 197. [CrossRef] 
13. Gyrd-Hansen, M.; Darding, M.; Miasari, M.; Santoro, M.M.; Zender, L.; Xue, W.; Tenev, T.; da Fonseca, P.C.A.; Zvelebil, M.; Bujnicki, J.M.; et al. IAPs contain an evolutionarily conserved ubiquitin-binding domain that regulates NF-kB as well as cell survival and oncogenesis. Nat. Cell Biol. 2008, 10, 1309-1317. [CrossRef] [PubMed]

14. Darding, M.; Feltham, R.; Tenev, T.; Bianchi, K.; Benetatos, C.; Silke, J.; Meier, P. Molecular determinants of Smac mimetic induced degradation of cIAP1 and cIAP2. Cell Death Differ. 2011, 18, 1376-1386. [CrossRef]

15. Silke, J.; Ekert, P.G.; Day, C.L.; Hawkins, C.J.; Baca, M.; Chew, J.; Pakusch, M.; Verhagen, A.M.; Vaux, D.L. Direct inhibition of caspase 3 is dispensable for the anti-apoptotic activity of XIAP. EMBO J. 2001, 20, 3114-3123. [CrossRef] [PubMed]

16. Galbán, S.; Hwang, C.; Rumble, J.M.; Oetjen, K.A.; Wright, C.W.; Boudreault, A.; Durkin, J.; Gillard, J.W.; Jaquith, J.B.; Morris, S.J.; et al. Cytoprotective effects of IAPs revealed by a small molecule antagonist. Biochem. J. 2009, 417, 765-771.

17. Varfolomeev, E.; Blankenship, J.W.; Wayson, S.M.; Fedorova, A.V.; Kayagaki, N.; Garg, P.; Zobel, K.; Dynek, J.N.; Elliott, L.O.; Wallweber, H.J.A.; et al. IAP antagonists induce autoubiquitination of c-IAPs, NF-kB activation, and TNF $\alpha$-dependent apoptosis. Cell 2007, 131, 669-681. [CrossRef]

18. Bertrand, M.J.; Milutinovic, S.; Dickson, K.M.; Ho, W.C.; Boudreault, A.; Durkin, J.; Gillard, J.W.; Jaquith, J.B.; Morris, S.J.; Barker, P.A. cIAP1 and cIAP2 facilitate cancer cell survival by functioning as E3 ligases that promote RIP1 ubiquitination. Mol. Cell 2008, 30, 689-700. [CrossRef]

19. Mahoney, D.J.; Cheung, H.H.; Mrad, R.L.; Plenchette, S.; Simard, C.; Enwere, E.; Arora, V.; Mak, T.W.; Lacasse, E.C.; Waring, J.; et al. Both cIAP1 and cIAP2 regulate TNF $\alpha$-mediated NF-кB activation. Proc. Natl. Acad. Sci. USA 2008, 105, 11778-11783. [CrossRef]

20. Vince, J.E.; Wong, W.W.; Khan, N.; Feltham, R.; Chau, D.; Ahmed, A.U.; Benetatos, C.A.; Chunduru, S.K.; Condon, S.M.; McKinlay, M.; et al. IAP antagonists target cIAP1 to induce TNFalpha-dependent apoptosis. Cell 2007, 131, 682-693. [CrossRef]

21. Dowling, J.P.; Alsabbagh, M.; Del Casale, C.; Liu, Z.-G.; Zhang, J. TRADD regulates perinatal development and adulthood survival in mice lacking RIPK1 and RIPK3. Nat. Commun. 2019, 10, 705. [CrossRef] [PubMed]

22. Füllsack, S.; Rosenthal, A.; Wajant, H.; Siegmund, D. Redundant and receptor-specific activities of TRADD, RIPK1 and FADD in death receptor signaling. Cell Death Dis. 2019, 10, 122. [CrossRef] [PubMed]

23. Anderton, H.; Bandala-Sanchez, E.; Simpson, D.S.; Rickard, J.A.; Ng, A.P.; Di Rago, L.; Hall, C.; Vince, J.E.; Silke, J.; Liccardi, G.; et al. RIPK1 prevents TRADD-driven, but TNFR1 independent, apoptosis during development. Cell Death Differ. 2019, 26, 877. [CrossRef] [PubMed]

24. Mace, P.D.; Smits, C.; Vaux, D.L.; Silke, J.; Day, C.L. Asymmetric recruitment of cIAPs by TRAF2. J. Mol. Biol. 2010, 400, 8-15. [CrossRef]

25. Zheng, C.; Kabaleeswaran, V.; Wang, Y.; Cheng, G.; Wu, H. Crystal structures of the TRAF2: cIAP2 and the TRAF1: TRAF2: cIAP2 complexes: Affinity, specificity, and regulation. Mol. Cell 2010, 38, 101-113. [CrossRef]

26. Vanden Berghe, T.; Kaiser, W.J.; Bertrand, M.J.M.; Vandenabeele, P. Molecular crosstalk between apoptosis, necroptosis, and survival signaling. Mol. Cell. Oncol. 2015, 2, 975093. [CrossRef]

27. Fulda, S.; Vucic, D. Targeting IAP proteins for therapeutic intervention in cancer. Nat. Rev. Drug Discov. 2012, 11, 109-124. [CrossRef]

28. Gerlach, B.; Cordier, S.M.; Schmukle, A.C.; Emmerich, C.H.; Rieser, E.; Haas, T.L.; Webb, A.I.; Rickard, J.A.; Anderton, H.; Wong, W.W.L.; et al. Linear ubiquitination prevents inflammation and regulates immune signalling. Nature 2011, 471, 591-596. [CrossRef]

29. Jaco, I.; Annibaldi, A.; Lalaoui, N.; Wilson, R.; Tenev, T.; Laurien, L.; Kim, C.; Jamal, K.; John, S.W.; Liccardi, G.; et al. MK2 phosphorylates RIPK1 to prevent TNF-induced cell death. Mol. Cell 2017, 66, 698-710. [CrossRef]

30. Menon, M.B.; Gropengießer, J.; Fischer, J.; Novikova, L.; Deuretzbacher, A.; Lafera, J.; Schimmeck, H.; Czymmeck, N.; Ronkina, N.; Kotlyarov, A.; et al. p38MAPK/MK2-dependent phosphorylation controls cytotoxic RIPK1 signalling in inflammation and infection. Nat. Cell Biol. 2017, 19, 1248. [CrossRef] [PubMed]

31. Dondelinger, Y.; Delanghe, T.; Rojas-Rivera, D.; Priem, D.; Delvaeye, T.; Bruggeman, I.; Van Herreweghe, F.; Vandenabeele, P.; Bertrand, M.J.M. MK2 phosphorylation of RIPK1 regulates TNF-mediated cell death. Nat. Cell Biol. 2017, 19, 1237. [CrossRef] [PubMed] 
32. Annibaldi, A.; John, S.W.; Berghe, T.V.; Swatek, K.N.; Ruan, J.; Liccardi, G.; Bianchi, K.; Elliott, P.R.; Choi, S.M.; Van Coillie, S.; et al. Ubiquitin-mediated regulation of RIPK1 kinase activity independent of IKK and MK2. Mol. Cell 2018, 69, 566-580. [CrossRef] [PubMed]

33. Silke, J.; Hawkins, C.J.; Ekert, P.G.; Chew, J.; Day, C.L.; Pakusch, M.; Verhagen, A.M.; Vaux, D.L. The anti-apoptotic activity of XIAP is retained upon mutation of both the caspase 3-and caspase 9-interacting sites. J. Cell Biol. 2002, 157, 115-124. [CrossRef] [PubMed]

34. Bratton, S.B.; Walker, G.; Srinivasula, S.M.; Sun, X.-M.; Butterworth, M.; Alnemri, E.S.; Cohen, G.M. Recruitment, activation and retention of caspases- 9 and -3 by Apaf- 1 apoptosome and associated XIAP complexes. EMBO J. 2001, 20, 998-1009. [CrossRef]

35. Wu, G.; Chai, J.; Suber, T.L.; Wu, J.-W.; Du, C.; Wang, X.; Shi, Y. Structural basis of IAP recognition by Smac/DIABLO. Nature 2000, 408, 1008-1012. [CrossRef]

36. Hegde, R.; Srinivasula, S.M.; Zhang, Z.; Wassell, R.; Mukattash, R.; Cilenti, L.; DuBois, G.; Lazebnik, Y.; Zervos, A.S.; Fernandes-Alnemri, T.; et al. Identification of Omi/HtrA2 as a mitochondrial apoptotic serine protease that disrupts inhibitor of apoptosis protein-caspase interaction. J. Biol. Chem. 2002, 277, 432-438. [CrossRef]

37. Ekert, P.G.; Silke, J.; Hawkins, C.J.; Verhagen, A.M.; Vaux, D.L. DIABLO promotes apoptosis by removing MIHA/XIAP from processed caspase 9. J. Cell Biol. 2001, 152, 483-490. [CrossRef]

38. Feltham, R.; Bettjeman, B.; Budhidarmo, R.; Mace, P.D.; Shirley, S.; Condon, S.M.; Chunduru, S.K.; McKinlay, M.A.; Vaux, D.L.; Silke, J.; et al. Smac mimetics activate the E3 ligase activity of cIAP1 protein by promoting RING domain dimerization. J. Biol. Chem. 2011, 286, 17015-17028. [CrossRef]

39. Dueber, E.C.; Schoeffler, A.J.; Lingel, A.; Elliott, J.M.; Fedorova, A.V.; Giannetti, A.M.; Zobel, K.; Maurer, B.; Varfolomeev, E.; Wu, P.; et al. Antagonists induce a conformational change in cIAP1 that promotes autoubiquitination. Science 2011, 334, 376-380. [CrossRef]

40. Hu, S.; Yang, X. Cellular inhibitor of apoptosis 1 and 2 are ubiquitin ligases for the apoptosis inducer Smac/DIABLO. J. Biol. Chem. 2003, 278, 10055-10060. [CrossRef]

41. Yang, Q.-H.; Du, C. Smac/DIABLO Selectively Reduces the Levels of c-IAP1 and c-IAP2 but Not That of XIAP and Livin in HeLa Cells. J. Biol. Chem. 2004, 279, 16963-16970. [CrossRef]

42. Creagh, E.M.; Murphy, B.M.; Duriez, P.J.; Duckett, C.S.; Martin, S.J. Smac/Diablo antagonizes ubiquitin ligase activity of inhibitor of apoptosis proteins. J. Biol. Chem. 2004, 279, 26906-26914. [CrossRef]

43. Micheau, O.; Tschopp, J. Induction of TNF receptor I-mediated apoptosis via two sequential signaling complexes. Cell 2003, 114, 181-190. [CrossRef]

44. Kitson, J.; Raven, T.; Jiang, Y.-P.; Goeddel, D.V.; Giles, K.M.; Pun, K.-T.; Grinham, C.J.; Brown, R.; Farrow, S.N. A death-domain-containing receptor that mediates apoptosis. Nature 1996, 384, 372-375. [CrossRef] [PubMed]

45. Dickens, L.S.; Boyd, R.S.; Jukes-Jones, R.; Hughes, M.A.; Robinson, G.L.; Fairall, L.; Schwabe, J.W.; Cain, K.; MacFarlane, M. A death effector domain chain DISC model reveals a crucial role for caspase- 8 chain assembly in mediating apoptotic cell death. Mol. Cell 2012, 47, 291-305. [CrossRef] [PubMed]

46. Chen, D.; Yu, J.; Zhang, L. Necroptosis: An alternative cell death program defending against cancer. Biochim. Et Biophys. Acta (BBA)-Rev. Cancer 2016, 1865, 228-236. [CrossRef]

47. Murphy, J.M.; Czabotar, P.E.; Hildebrand, J.M.; Lucet, I.S.; Zhang, J.-G.; Alvarez-Diaz, S.; Lewis, R.; Lalaoui, N.; Metcalf, D.; Webb, A.I.; et al. The pseudokinase MLKL mediates necroptosis via a molecular switch mechanism. Immunity 2013, 39, 443-453. [CrossRef]

48. Murphy, J.M.; Silke, J. Ars Moriendi; the art of dying well-new insights into the molecular pathways of necroptotic cell death. EMBO Rep. 2014, 15, 155-164. [CrossRef]

49. Wang, H.; Sun, L.; Su, L.; Rizo, J.; Liu, L.; Wang, L.-F.; Wang, F.-S.; Wang, X. Mixed lineage kinase domain-like protein MLKL causes necrotic membrane disruption upon phosphorylation by RIP3. Mol. Cell 2014, 54, 133-146. [CrossRef]

50. Condon, S.M.; Mitsuuchi, Y.; Deng, Y.; LaPorte, M.G.; Rippin, S.R.; Haimowitz, T.; Alexander, M.D.; Kumar, P.T.; Hendi, M.S.; Lee, Y.H.; et al. Birinapant, a smac-mimetic with improved tolerability for the treatment of solid tumors and hematological malignancies. J. Med. Chem. 2014, 57, 3666-3677. [CrossRef]

51. Zender, L.; Spector, M.S.; Xue, W.; Flemming, P.; Cordon-Cardo, C.; Silke, J.; Fan, S.-T.; Luk, J.M.; Wigler, M.; Hannon, G.J.; et al. Identification and Validation of Oncogenes in Liver Cancer Using an Integrative Oncogenomic Approach. Cell 2006, 125, 1253-1267. [CrossRef] [PubMed] 
52. Fulda, S.; Wick, W.; Weller, M.; Debatin, K.-M. Smac agonists sensitize for Apo2L/TRAIL-or anticancer drug-induced apoptosis and induce regression of malignant glioma in vivo. Nat. Med. 2002, 8, 808. [CrossRef] [PubMed]

53. Carter, B.Z.; Milella, M.; Tsao, T.; McQueen, T.; Schober, W.; Hu, W.; Dean, N.; Steelman, L.; McCubrey, J.; Andreeff, M. Regulation and targeting of antiapoptotic XIAP in acute myeloid leukemia. Leukemia 2003, 17, 2081-2089. [CrossRef] [PubMed]

54. Arnt, C.R.; Chiorean, M.V.; Heldebrant, M.P.; Gores, G.J.; Kaufmann, S.H. Synthetic Smac/DIABLO peptides enhance the effects of chemotherapeutic agents by binding XIAP and cIAP1 in situ. J. Biol. Chem. 2002, 277, 44236-44243. [CrossRef] [PubMed]

55. Silke, J.; Verhagen, A.M.; Ekert, P.G.; Vaux, D.L. Sequence as well as functional similarity for DIABLO/Smac and Grim, Reaper and Hid? Cell Death Differ. 2000, 7, 1275. [CrossRef] [PubMed]

56. Kipp, R.A.; Case, M.A.; Wist, A.D.; Cresson, C.M.; Carrell, M.; Griner, E.; Wiita, A.; Albiniak, P.A.; Chai, J.; Shi, Y.; et al. Molecular Targeting of Inhibitor of Apoptosis Proteins Based on Small Molecule Mimics of Natural Binding Partners. Biochemistry 2002, 41, 7344-7349. [CrossRef]

57. Schimmer, A.D.; Welsh, K.; Pinilla, C.; Wang, Z.; Krajewska, M.; Bonneau, M.-J.; Pedersen, I.M.; Kitada, S.; Scott, F.L.; Bailly-Maitre, B.; et al. Small-molecule antagonists of apoptosis suppressor XIAP exhibit broad antitumor activity. Cancer Cell 2004, 5, 25-35. [CrossRef]

58. Oost, T.K.; Sun, C.; Armstrong, R.C.; Al-Assaad, A.-S.; Betz, S.F.; Deckwerth, T.L.; Ding, H.; Elmore, S.W.; Meadows, R.P.; Olejniczak, E.T.; et al. Discovery of potent antagonists of the antiapoptotic protein XIAP for the treatment of cancer. J. Med. Chem. 2004, 47, 4417-4426. [CrossRef]

59. Li, L.; Thomas, R.M.; Suzuki, H.; De Brabander, J.K.; Wang, X.; Harran, P.G. A small molecule Smac mimic potentiates TRAIL-and TNF $\alpha$-mediated cell death. Science 2004, 305, 1471-1474. [CrossRef]

60. Zobel, K.; Wang, L.; Varfolomeev, E.; Franklin, M.C.; Elliott, L.O.; Wallweber, H.J.; Okawa, D.C.; Flygare, J.A.; Vucic, D.; Fairbrother, W.J.; et al. Design, synthesis, and biological activity of a potent Smac mimetic that sensitizes cancer cells to apoptosis by antagonizing IAPs. ACS Chem. Biol. 2006, 1, 525-533. [CrossRef]

61. Chai, J.; Du, C.; Wu, J.-W.; Kyin, S.; Wang, X.; Shi, Y. Structural and biochemical basis of apoptotic activation by Smac/DIABLO. Nature 2000, 406, 855-862. [CrossRef] [PubMed]

62. Moulin, M.; Anderton, H.; Voss, A.K.; Thomas, T.; Wong, W.W.L.; Bankovacki, A.; Feltham, R.; Chau, D.; Cook, W.D.; Silke, J.; et al. IAPs limit activation of RIP kinases by TNF receptor 1 during development. EMBO J. 2012, 31, 1679-1691. [CrossRef] [PubMed]

63. Heard, K.N.; Bertrand, M.J.; Barker, P.A. cIAP2 supports viability of mice lacking cIAP1 and XIAP. EMBO J. 2015, 34, 2393-2395. [CrossRef] [PubMed]

64. Vince, J.E.; Wong, W.W.-L.; Gentle, I.; Lawlor, K.E.; Allam, R.; O’Reilly, L.; Mason, K.; Gross, O.; Ma, S.; Guarda, G.; et al. Inhibitor of apoptosis proteins limit RIP3 kinase-dependent interleukin-1 activation. Immunity 2012, 36, 215-227. [CrossRef]

65. Anderton, H.; Rickard, J.A.; Varigos, G.A.; Lalaoui, N.; Silke, J. Inhibitor of apoptosis proteins (IAPs) limit RIPK1-mediated skin inflammation. J. Investig. Dermatol. 2017, 137, 2371-2379. [CrossRef]

66. Ndubaku, C.; Varfolomeev, E.; Wang, L.; Zobel, K.; Lau, K.; Elliott, L.O.; Maurer, B.; Fedorova, A.V.; Dynek, J.N.; Koehler, M.; et al. Antagonism of c-IAP and XIAP proteins is required for efficient induction of cell death by small-molecule IAP antagonists. ACS Chem. Biol. 2009, 4, 557-566. [CrossRef]

67. Benetatos, C.A.; Mitsuuchi, Y.; Burns, J.M.; Neiman, E.M.; Condon, S.M.; Yu, G.; Seipel, M.E.; Kapoor, G.S.; LaPorte, M.G.; Rippin, S.R.; et al. Birinapant (TL32711), a bivalent SMAC mimetic, targets TRAF2-associated cIAPs, abrogates TNF-induced NF- $\mathrm{B}$ activation, and is active in patient-derived xenograft models. Mol. Cancer Ther. 2014, 13, 867-879. [CrossRef]

68. Krepler, C.; Chunduru, S.K.; Halloran, M.B.; He, X.; Xiao, M.; Vultur, A.; Villanueva, J.; Mitsuuchi, Y.; Neiman, E.M.; Benetatos, C.; et al. The novel SMAC mimetic birinapant exhibits potent activity against human melanoma cells. Clin. Cancer Res. 2013, 19, 1784-1794. [CrossRef]

69. Coussens, L.M.; Werb, Z. Inflammation and cancer. Nature 2002, 420, 860. [CrossRef]

70. Katerinaki, E.; Evans, G.; Lorigan, P.; MacNeil, S. TNF- $\alpha$ increases human melanoma cell invasion and migration in vitro: The role of proteolytic enzymes. Br. J. Cancer 2003, 89, 1123. [CrossRef]

71. Beug, S.T.; Tang, V.A.; LaCasse, E.C.; Cheung, H.H.; Beauregard, C.E.; Brun, J.; Nuyens, J.P.; Earl, N.; St-Jean, M.; Holbrook, J.; et al. Smac mimetics and innate immune stimuli synergize to promote tumor death. Nat. Biotechnol. 2014, 32, 182. [CrossRef] [PubMed] 
72. Chesi, M.; Mirza, N.N.; Garbitt, V.M.; Sharik, M.E.; Dueck, A.C.; Asmann, Y.W.; Akhmetzyanova, I.; Kosiorek, H.E.; Calcinotto, A.; Riggs, D.L.; et al. IAP antagonists induce anti-tumor immunity in multiple myeloma. Nat. Med. 2016, 22, 1411. [CrossRef] [PubMed]

73. Michie, J.; Beavis, P.A.; Freeman, A.J.; Vervoort, S.J.; Ramsbottom, K.M.; Narasimhan, V.; Lelliott, E.J.; Lalaoui, N.; Ramsay, R.G.; Johnstone, R.W.; et al. Antagonism of IAPs enhances CAR T-cell efficacy. Cancer Immunol. Res. 2019, 7, 183-192. [CrossRef] [PubMed]

74. Eytan, D.F.; Snow, G.E.; Carlson, S.; Derakhshan, A.; Saleh, A.; Schiltz, S.; Cheng, H.; Mohan, S.; Cornelius, S.; Coupar, J.; et al. SMAC mimetic birinapant plus radiation eradicates human head and neck cancers with genomic amplifications of cell death genes FADD and BIRC2. Cancer Res. 2016, 76, 5442-5454. [CrossRef] [PubMed]

75. Network, C.G.A. Comprehensive genomic characterization of head and neck squamous cell carcinomas. Nature 2015, 517, 576. [CrossRef] [PubMed]

76. Eytan, D.F.; Snow, G.E.; Carlson, S.G.; Schiltz, S.; Chen, Z.; Van Waes, C. Combination effects of SMAC mimetic birinapant with TNF $\alpha$, TRAIL, and docetaxel in preclinical models of HNSCC. Laryngoscope 2015, 125, E118-E124. [CrossRef]

77. Allensworth, J.L.; Aird, K.M.; Aldrich, A.J.; Batinic-Haberle, I.; Devi, G.R. XIAP Inhibition and Generation of Reactive Oxygen Species Enhances TRAIL Sensitivity in Inflammatory Breast Cancer Cells. Mol. Cancer Ther. 2012, 11, 1518-1527. [CrossRef]

78. Allensworth, J.L.; Sauer, S.J.; Lyerly, H.K.; Morse, M.A.; Devi, G.R. Smac mimetic Birinapant induces apoptosis and enhances TRAIL potency in inflammatory breast cancer cells in an IAP-dependent and TNF- $\alpha$-independent mechanism. Breast Cancer Res. Treat. 2013, 137, 359-371. [CrossRef]

79. Amaravadi, R.K.; Schilder, R.J.; Martin, L.P.; Levin, M.; Graham, M.A.; Weng, D.E.; Adjei, A.A. A Phase I Study of the SMAC-Mimetic Birinapant in Adults with Refractory Solid Tumors or Lymphoma. Mol. Cancer Ther. 2015, 14, 2569-2575. [CrossRef]

80. Frey, N.V.; Luger, S.; Mangan, J.; Zebrowski, A.; Loren, A.W.; Minderman, H.; Baird, J.; Porter, D.L.; Hexner, E.O.; Kumar, A.J.; et al. Abstract: A phase I study using single agent birinapant in patients with relapsed myelodysplastic syndrome and acute myelogenous leukemia. Blood 2014, 124, 3758. [CrossRef]

81. Noonan, A.M.; Bunch, K.P.; Chen, J.Q.; Herrmann, M.A.; Lee, J.M.; Kohn, E.C.; O'sullivan, C.C.; Jordan, E.; Houston, N.; Takebe, N.; et al. Pharmacodynamic markers and clinical results from the phase 2 study of the SMAC mimetic birinapant in women with relapsed platinum-resistant or-refractory epithelial ovarian cancer. Cancer 2016, 122, 588-597. [CrossRef] [PubMed]

82. Weisberg, E.; Ray, A.; Barrett, R.; Nelson, E.; Christie, A.L.; Porter, D.; Straub, C.; Zawel, L.; Daley, J.F.; Lazo-Kallanian, S.; et al. Smac mimetics: Implications for enhancement of targeted therapies in leukemia. Leukemia 2010, 24, 2100. [CrossRef] [PubMed]

83. Weisberg, E.; Kung, A.L.; Wright, R.D.; Moreno, D.; Catley, L.; Ray, A.; Zawel, L.; Tran, M.; Cools, J.; Gilliland, G.; et al. Potentiation of antileukemic therapies by Smac mimetic, LBW242: Effects on mutant FLT3-expressing cells. Mol. Cancer Ther. 2007, 6, 1951-1961. [CrossRef] [PubMed]

84. Condon, S.M. The discovery and development of Smac mimetics—small-molecule antagonists of the inhibitor of apoptosis proteins. In Annual reports in Medicinal Chemistry; Elsevier: Amsterdam, The Netherlands, 2011; Volume 46, pp. 211-226.

85. Hird, A.W.; Aquila, B.M.; Hennessy, E.J.; Vasbinder, M.M.; Yang, B. Small molecule inhibitor of apoptosis proteins antagonists: A patent review. Expert Opin. Ther. Pat. 2015, 25, 755-774. [CrossRef] [PubMed]

86. Chen, K.-F.; Lin, J.-P.; Shiau, C.-W.; Tai, W.-T.; Liu, C.-Y.; Yu, H.-C.; Chen, P.-J.; Cheng, A.-L. Inhibition of Bcl-2 improves effect of LCL161, a SMAC mimetic, in hepatocellular carcinoma cells. Biochem. Pharmacol. 2012, 84, 268-277. [CrossRef]

87. Ramakrishnan, V.; Painuly, U.; Kimlinger, T.; Haug, J.; Rajkumar, S.V.; Kumar, S. Inhibitor of apoptosis proteins as therapeutic targets in multiple myeloma. Leukemia 2014, 28, 1519. [CrossRef]

88. Houghton, P.J.; Kang, M.H.; Reynolds, C.P.; Morton, C.L.; Kolb, E.A.; Gorlick, R.; Keir, S.T.; Carol, H.; Lock, R.; Maris, J.M.; et al. Initial testing (stage 1) of LCL161, a SMAC mimetic, by the Pediatric Preclinical Testing Program. Pediatr. Blood Cancer 2012, 58, 636-639. [CrossRef] [PubMed]

89. Neale, G.; Su, X.; Morton, C.L.; Phelps, D.; Gorlick, R.; Lock, R.B.; Reynolds, C.P.; Maris, J.M.; Friedman, H.S.; Dome, J.; et al. Molecular characterization of the pediatric preclinical testing panel. Clin. Cancer Res. 2008, 14, 4572-4583. [CrossRef] 
90. Faye, M.; Beug, S.; Graber, T.; Earl, N.; Xiang, X.; Wild, B.; Langlois, S.; Michaud, J.; Cowan, K.; Korneluk, R.; et al. IGF2BP1 controls cell death and drug resistance in rhabdomyosarcomas by regulating translation of cIAP1. Oncogene 2015, 34, 1532. [CrossRef]

91. Infante, J.R.; Dees, E.C.; Olszanski, A.J.; Dhuria, S.V.; Sen, S.; Cameron, S.; Cohen, R.B. Phase I dose-escalation study of LCL161, an oral inhibitor of apoptosis proteins inhibitor, in patients with advanced solid tumors. J. Clin. Oncol. 2014, 32, 3103-3110. [CrossRef]

92. Cai, Q.; Sun, H.; Peng, Y.; Lu, J.; Nikolovska-Coleska, Z.; McEachern, D.; Liu, L.; Qiu, S.; Yang, C.-Y.; Miller, R.; et al. A potent and orally active antagonist (SM-406/AT-406) of multiple inhibitor of apoptosis proteins (IAPs) in clinical development for cancer treatment. J. Med. Chem. 2011, 54, 2714-2726. [CrossRef] [PubMed]

93. Brunckhorst, M.K.; Lerner, D.; Wang, S.; Yu, Q. AT-406, an orally active antagonist of multiple inhibitor of apoptosis proteins, inhibits progression of human ovarian cancer. Cancer Biol. Ther. 2012, 13, 804-811. [CrossRef] [PubMed]

94. Zhang, T.; Li, Y.; Zou, P.; Yu, J.y.; McEachern, D.; Wang, S.; Sun, D. Physiologically based pharmacokinetic and pharmacodynamic modeling of an antagonist (SM-406/AT-406) of multiple inhibitor of apoptosis proteins (IAPs) in a mouse xenograft model of human breast cancer. Biopharm. Drug Dispos. 2013, 34, 348-359. [CrossRef] [PubMed]

95. Hurwitz, H.I.; Smith, D.C.; Pitot, H.C.; Brill, J.M.; Chugh, R.; Rouits, E.; Rubin, J.; Strickler, J.; Vuagniaux, G.; Sorensen, J.M.; et al. Safety, pharmacokinetics, and pharmacodynamic properties of oral DEBIO1143 (AT-406) in patients with advanced cancer: Results of a first-in-man study. Cancer Chemother. Pharmacol. 2015, 75, 851-859. [CrossRef]

96. Flygare, J.A.; Beresini, M.; Budha, N.; Chan, H.; Chan, I.T.; Cheeti, S.; Cohen, F.; Deshayes, K.; Doerner, K.; Eckhardt, S.G.; et al. Discovery of a potent small-molecule antagonist of inhibitor of apoptosis (IAP) proteins and clinical candidate for the treatment of cancer (GDC-0152). J. Med. Chem. 2012, 55, 4101-4113. [CrossRef]

97. Wong, H.; Gould, S.E.; Budha, N.; Darbonne, W.C.; Kadel, E.E.; La, H.; Alicke, B.; Halladay, J.S.; Erickson, R.; Portera, C.; et al. Learning and confirming with preclinical studies: Modeling and simulation in the discovery of GDC-0917, an inhibitor of apoptosis proteins antagonist. Drug Metab. Dispos. 2013, 41, 2104-2113. [CrossRef]

98. Tchoghandjian, A.; Soubéran, A.; Tabouret, E.; Colin, C.; Denicolaï, E.; Jiguet-Jiglaire, C.; El-Battari, A.; Villard, C.; Baeza-Kallee, N.; Figarella-Branger, D. Inhibitor of apoptosis protein expression in glioblastomas and their in vitro and in vivo targeting by SMAC mimetic GDC-0152. Cell Death Dis. 2016, 7, 2325. [CrossRef]

99. Tolcher, A.W.; Bendell, J.C.; Papadopoulos, K.P.; Burris, H.A.; Patnaik, A.; Fairbrother, W.J.; Wong, H.; Budha, N.; Darbonne, W.C.; Peale, F.; et al. A phase I dose-escalation study evaluating the safety tolerability and pharmacokinetics of CUDC-427, a potent, oral, monovalent IAP antagonist, in patients with refractory solid tumors. Clin. Cancer Res. 2016, 22, 4567-4573. [CrossRef]

100. Ji, J.; Yu, Y.; Li, Z.-L.; Chen, M.-Y.; Deng, R.; Huang, X.; Wang, G.-F.; Zhang, M.-X.; Yang, Q.; Ravichandran, S.; et al. XIAP Limits Autophagic Degradation of Sox2 and is a therapeutic target in nasopharyngeal carcinoma stem cells. Theranostics 2018, 8, 1494. [CrossRef]

101. Li, B.-X.; Wang, H.-B.; Qiu, M.-Z.; Luo, Q.-Y.; Yi, H.-J.; Yan, X.-L.; Pan, W.-T.; Yuan, L.-P.; Zhang, Y.-X.; $\mathrm{Xu}, \mathrm{J} .-\mathrm{H}$.; et al. Novel smac mimetic APG-1387 elicits ovarian cancer cell killing through TNF-alpha, Ripoptosome and autophagy mediated cell death pathway. J. Exp. Clin. Cancer Res. 2018, 37, 53. [CrossRef]

102. Li, N.; Feng, L.; Han, H.-Q.; Yuan, J.; Qi, X.-K.; Lian, Y.-F.; Kuang, B.-H.; Zhang, Y.-C.; Deng, C.-C.; Zhang, H.-J.; et al. A novel Smac mimetic APG-1387 demonstrates potent antitumor activity in nasopharyngeal carcinoma cells by inducing apoptosis. Cancer Lett. 2016, 381, 14-22. [CrossRef] [PubMed]

103. Xu, R.; Li, Y.; Ji, J.; Qiu, M.; Zhang, Y.; Liu, W.; Tian, X.; Li, S.; Wang, H.; Wang, F.; et al. A phase I study of a novel IAP inhibitor APG-1387 in patients with advanced solid tumors. Am. Soc. Clin. Oncol. 2018, 36, 2593. [CrossRef]

104. Rasco, D.W.; Li, Y.; Tang, Y.; Men, L.; Wang, H.; Ji, J.; Liang, Z.; Sun, J.; Amaya, A.; Huang, Y.; et al. A phase I study of a novel IAP inhibitor APG-1387 as a monotherapy or in combination with pembrolizumab in treatments of patients with advanced solid tumors. Am. Soc. Clin. Oncol. 2019, 37, 3125. [CrossRef]

105. Humphreys, R.C.; Poortman, C.; McCormick, K.; Carrell, J.; Shepard, L. Abstract C10: A novel combination of a small molecule IAP inhibitor and a TRAIL-R1 monoclonal antibody synergize to induce apoptosis in pancreatic tumor cell lines. Mol. Cancer Ther. 2009, 8, C10. 
106. Eckhardt, S.G.; Gallant, G.; Sikic, B.I.; Camidge, D.R.; Burris III, H.A.; Wakelee, H.A.; Messersmith, W.A.; Jones, S.F.; Colevas, A.D.; Infante, J.R. Phase I study evaluating the safety, tolerability, and pharmacokinetics (PK) of HGS1029, a small-molecule inhibitor of apoptosis protein (IAP), in patients (pts) with advanced solid tumors. J. Clin. Oncol. 2010, 28, 2580. [CrossRef]

107. Sikic, B.I.; Eckhardt, S.G.; Gallant, G.; Burris, H.A.; Camidge, D.R.; Colevas, A.D.; Jones, S.F.; Messersmith, W.A.; Wakelee, H.A.; Li, H.; et al. Safety, pharmacokinetics (PK), and pharmacodynamics (PD) of HGS1029, an inhibitor of apoptosis protein (IAP) inhibitor, in patients (Pts) with advanced solid tumors: Results of a phase I study. J. Clin. Oncol. 2011, 29, 3008. [CrossRef]

108. Impagnatiello, M.A.; Reschke, M.; Reiser, U.; Scharn, D.; Spevak, W.; Savchenko, A.; Tirapu, I.; Wernitznig, A.; Sykora, M.; Langlois, R.; et al. BI5 (BI 891065): A Novel SMAC Mimetic that Triggers Tumor Cell Death and Potentiates PD-1 Mediated Cancer Therapy. In Proceedings of the AACR Annual Meeting, Washington, DC, USA, 1-5 April 2017.

109. Petersen, S.L.; Wang, L.; Yalcin-Chin, A.; Li, L.; Peyton, M.; Minna, J.; Harran, P.; Wang, X. Autocrine TNFalpha signaling renders human cancer cells susceptible to Smac-mimetic-induced apoptosis. Cancer Cell 2007, 12, 445-456. [CrossRef] [PubMed]

110. Gaither, A.; Porter, D.; Yao, Y.; Borawski, J.; Yang, G.; Donovan, J.; Sage, D.; Slisz, J.; Tran, M.; Straub, C.; et al. A Smac mimetic rescue screen reveals roles for inhibitor of apoptosis proteins in tumor necrosis factor- $\alpha$ signaling. Cancer Res. 2007, 67, 11493-11498. [CrossRef]

111. Roberts, N.J.; Zhou, S.; Diaz Jr, L.A.; Holdhoff, M. Systemic use of tumor necrosis factor alpha as an anticancer agent. Oncotarget 2011, 2, 739. [CrossRef]

112. Lejeune, F.J.; Liénard, D.; Matter, M.; Rüegg, C. Efficiency of recombinant human TNF in human cancer therapy. Cancer Immun. Arch. 2006, 6, 6.

113. Yuan, Z.; Syrkin, G.; Adem, A.; Geha, R.; Pastoriza, J.; Vrikshajanani, C.; Smith, T.; Quinn, T.; Alemu, G.; Cho, H.; et al. Blockade of inhibitors of apoptosis (IAPs) in combination with tumor-targeted delivery of tumor necrosis factor- $\alpha$ leads to synergistic antitumor activity. Cancer Gene Ther. 2013, 20, 46. [CrossRef] [PubMed]

114. Hajitou, A.; Trepel, M.; Lilley, C.E.; Soghomonyan, S.; Alauddin, M.M.; Marini, F.C.; Restel, B.H.; Ozawa, M.G.; Moya, C.A.; Rangel, R.; et al. A Hybrid Vector for Ligand-Directed Tumor Targeting and Molecular Imaging. Cell 2006, 125, 385-398. [CrossRef]

115. Hajitou, A.; Rangel, R.; Trepel, M.; Soghomonyan, S.; Gelovani, J.G.; Alauddin, M.M.; Pasqualini, R.; Arap, W. Design and construction of targeted AAVP vectors for mammalian cell transduction. Nat. Protoc. 2007, 2, 523. [CrossRef]

116. Beug, S.T.; Pichette, S.J.; St-Jean, M.; Holbrook, J.; Walker, D.E.; LaCasse, E.C.; Korneluk, R.G. Combination of IAP Antagonists and TNF- $\alpha$-Armed Oncolytic Viruses Induce Tumor Vascular Shutdown and Tumor Regression. Mol. Ther.-Oncolytics 2018, 10, 28-39. [CrossRef] [PubMed]

117. Lalaoui, N.; Hänggi, K.; Brumatti, G.; Chau, D.; Nguyen, N.-Y.; Vasilikos, L.; Spilgies, L.M.; Heckmann, D.A.; Ma, C.; Ghisi, M.; et al. Targeting p38 or MK2 Enhances the Anti-Leukemic Activity of Smac-Mimetics. Cancer Cell 2016, 29, 145-158. [CrossRef] [PubMed]

118. Hallahan, D.E.; Spriggs, D.R.; Beckett, M.A.; Kufe, D.W.; Weichselbaum, R.R. Increased tumor necrosis factor alpha mRNA after cellular exposure to ionizing radiation. Proc. Natl. Acad. Sci. USA 1989, 86, 10104-10107. [CrossRef] [PubMed]

119. Qin, Q.; Zuo, Y.; Yang, X.; Lu, J.; Zhan, L.; Xu, L.; Zhang, C.; Zhu, H.; Liu, J.; Liu, Z.; et al. Smac mimetic compound LCL161 sensitizes esophageal carcinoma cells to radiotherapy by inhibiting the expression of inhibitor of apoptosis protein. Tumor Biol. 2014, 35, 2565-2574. [CrossRef]

120. Liu, N.; Tao, Z.; Le Blanc, J.M.; Zaorsky, N.G.; Sun, Y.; Vuagniaux, G.; Dicker, A.P.; Lu, B. Debio 1143, an antagonist of multiple inhibitor-of-apoptosis proteins, activates apoptosis and enhances radiosensitization of non-small cell lung cancer cells in vitro. Am. J. Cancer Res. 2014, 4, 943.

121. Matzinger, O.; Viertl, D.; Tsoutsou, P.; Kadi, L.; Rigotti, S.; Zanna, C.; Wiedemann, N.; Vozenin, M.-C.; Vuagniaux, G.; Bourhis, J. The radiosensitizing activity of the SMAC-mimetic, Debio 1143, is TNF $\alpha$-mediated in head and neck squamous cell carcinoma. Radiother. Oncol. 2015, 116, 495-503. [CrossRef]

122. Adrain, C.; Creagh, E.M.; Martin, S.J. Apoptosis-associated release of Smac/DIABLO from mitochondria requires active caspases and is blocked by Bcl-2. EMBO J. 2001, 20, 6627-6636. [CrossRef] 
123. Chu, Q.; Vincent, M.; Logan, D.; Mackay, J.A.; Evans, W.K.; Lung Cancer Disease Site Group of Cancer Care Ontario's Program in Evidence-based Care. Taxanes as first-line therapy for advanced non-small cell lung cancer: A systematic review and practice guideline. Lung Cancer 2005, 50, 355-374. [CrossRef] [PubMed]

124. Yang, C.; Wang, H.; Zhang, B.; Chen, Y.; Zhang, Y.; Sun, X.; Xiao, G.; Nan, K.; Ren, H.; Qin, S. LCL161 increases paclitaxel-induced apoptosis by degrading cIAP1 and CIAP2 in NSCLC. J. Exp. Clin. Cancer Res. 2016, 35, 158. [CrossRef] [PubMed]

125. Tanimoto, T.; Tsuda, H.; Imazeki, N.; Ohno, Y.; Imoto, I.; Inazawa, J.; Matsubara, O. Nuclear expression of CIAP-1, an apoptosis inhibiting protein, predicts lymph node metastasis and poor patient prognosis in head and neck squamous cell carcinomas. Cancer Lett. 2005, 224, 141-151. [CrossRef] [PubMed]

126. Esposito, I.; Kleeff, J.; Abiatari, I.; Shi, X.; Giese, N.; Bergmann, F.; Roth, W.; Friess, H.; Schirmacher, P. Overexpression of cellular inhibitor of apoptosis protein 2 is an early event in the progression of pancreatic cancer. J. Clin. Pathol. 2007, 60, 885-895. [CrossRef] [PubMed]

127. Dai, Z.; Zhu, W.-G.; Morrison, C.D.; Brena, R.M.; Smiraglia, D.J.; Raval, A.; Wu, Y.-Z.; Rush, L.J.; Ross, P.; Molina, J.R.; et al. A comprehensive search for DNA amplification in lung cancer identifies inhibitors of apoptosis cIAP1 and cIAP2 as candidate oncogenes. Hum. Mol. Genet. 2003, 12, 791-801. [CrossRef] [PubMed]

128. Cannistra, S.A. Cancer of the ovary. New Engl. J. Med. 2004, 351, 2519-2529. [CrossRef]

129. Cannistra, S.A. Cancer of the ovary. New Engl. J. Med. 1993, 329, 1550-1559. [CrossRef]

130. Janzen, D.; Tiourin, E.; Salehi, J.; Paik, D.; Lu, J.; Pellegrini, M.; Memarzadeh, S. An apoptosis-enhancing drug overcomes platinum resistance in a tumour-initiating subpopulation of ovarian cancer. Nat. Commun. 2015, 6, 7956. [CrossRef]

131. Thibault, B.; Genre, L.; Le Naour, A.; Broca, C.; Mery, E.; Vuagniaux, G.; Delord, J.P.; Wiedemann, N.; Couderc, B. DEBIO 1143, an IAP inhibitor, reverses carboplatin resistance in ovarian cancer cells and triggers apoptotic or necroptotic cell death. Sci. Rep. 2018, 8, 17862. [CrossRef]

132. Amaravadi, R.K.; Senzer, N.N.; Martin, L.P.; Schilder, R.J.; LoRusso, P.; Papadopoulos, K.P.; Weng, D.E.; Graham, M.; Adjei, A.A. A phase I study of birinapant (TL32711) combined with multiple chemotherapies evaluating tolerability and clinical activity for solid tumor patients. J. Clin. Oncol. 2013, 31, 2504.

133. Senzer, N.N.; LoRusso, P.; Martin, L.P.; Schilder, R.J.; Amaravadi, R.K.; Papadopoulos, K.P.; Segota, Z.E.; Weng, D.E.; Graham, M.; Adjei, A.A. Phase II clinical activity and tolerability of the SMAC-mimetic birinapant (TL32711) plus irinotecan in irinotecan-relapsed/refractory metastatic colorectal cancer. J. Clin. Oncol. 2013, $31,3621$.

134. Dienstmann, R.; Vidal, L.; Dees, E.; Chia, S.; Mayer, E.; Porter, D.; Baney, T.; Dhuria, S.; Sen, S.; Firestone, B.; et al. Abstract P6-11-06: A phase Ib Study of LCL161, an oral Inhibitor of Apoptosis (IAP) Antagonist, in Combination with Weekly Paclitaxel in Patients with Advanced Solid Tumors; AACR: Philadelphia, PA, USA, 2012.

135. Bardia, A.; Cameron, J.S.; Venkatesan, K.; Robinson, D.; Porter, D.; Kim, S.B.; Parton, M.; Kümmel, S.; Estevez, L.G.; Huang, C.S.; et al. 1977 Synergy of LCL161, an antagonist of inhibitor of apoptosis proteins (IAPs), with paclitaxel in a gene expression signature-enriched cohort of triple-negative breast cancer (TNBC). Eur. J. Cancer 2015, 51, S326. [CrossRef]

136. Firestone, B.; Conway, C.; Yang, G.; Gao, H.; Porter, D.; Slisz, J.; He, D.; Mosher, R.; Monahan, J.; Straub, C.; et al. Abstract B27: Correlation between TNF $\alpha$ and LCL161 Anti-Tumor Activity in Patient Derived Xenograft Models of Human Cancer; AACR: Philadelphia, PA, USA, 2009.

137. Bardia, A.; Parton, M.; Kummel, S.; Estévez, L.G.; Huang, C.-S.; Cortés, J.; Ruiz-Borrego, M.; Telli, M.L.; Martin-Martorell, P.; López, R.; et al. Paclitaxel with inhibitor of apoptosis antagonist, LCL161, for localized triple-negative breast cancer, prospectively stratified by gene signature in a biomarker-driven neoadjuvant trial. J. Clin. Oncol. 2018, 36, 3126-3133. [CrossRef] [PubMed]

138. Kluck, R.M.; Bossy-Wetzel, E.; Green, D.R.; Newmeyer, D.D. The release of cytochrome c from mitochondria: A primary site for Bcl-2 regulation of apoptosis. Science 1997, 275, 1132-1136. [CrossRef]

139. Yang, J.; Liu, X.; Bhalla, K.; Kim, C.N.; Ibrado, A.M.; Cai, J.; Peng, T.-I.; Jones, D.P.; Wang, X. Prevention of apoptosis by Bcl-2: Release of cytochrome c from mitochondria blocked. Science 1997, 275, 1129-1132. [CrossRef]

140. Delbridge, A.R.; Grabow, S.; Strasser, A.; Vaux, D.L. Thirty years of BCL-2: Translating cell death discoveries into novel cancer therapies. Nat. Rev. Cancer 2016, 16, 99. [CrossRef] 
141. Pettersson, M.; Jernberg-Wiklund, H.; Larsson, L.; Sundstrom, C.; Givol, I.; Tsujimoto, Y.; Nilsson, K. Expression of the bcl-2 gene in human multiple myeloma cell lines and normal plasma cells. Blood 1992, 79, 495-502. [CrossRef]

142. Wuilleme-Toumi, S.; Robillard, N.; Gomez, P.; Moreau, P.; Le Gouill, S.; Avet-Loiseau, H.; Harousseau, J.; Amiot, M.; Bataille, R. Mcl-1 is overexpressed in multiple myeloma and associated with relapse and shorter survival. Leukemia 2005, 19, 1248. [CrossRef]

143. Nakagawa, Y.; Abe, S.; Kurata, M.; Hasegawa, M.; Yamamoto, K.; Inoue, M.; Takemura, T.; Suzuki, K.; Kitagawa, M. IAP family protein expression correlates with poor outcome of multiple myeloma patients in association with chemotherapy-induced overexpression of multidrug resistance genes. Am. J. Hematol. 2006, 81, 824-831. [CrossRef]

144. Desplanques, G.; Giuliani, N.; Delsignore, R.; Rizzoli, V.; Bataille, R.; Barillé-Nion, S. Impact of XIAP protein levels on the survival of myeloma cells. Haematologica 2009, 94, 87-93. [CrossRef]

145. Ramakrishnan, V.; Gomez, M.; Prasad, V.; Kimlinger, T.; Painuly, U.; Mukhopadhyay, B.; Haug, J.; Bi, L.; Rajkumar, S.V.; Kumar, S. Smac mimetic LCL161 overcomes protective ER stress induced by obatoclax, synergistically causing cell death in multiple myeloma. Oncotarget 2016, 7, 56253. [CrossRef] [PubMed]

146. Vogler, M.; Weber, K.; Dinsdale, D.; Schmitz, I.; Schulze-Osthoff, K.; Dyer, M.; Cohen, G. Different forms of cell death induced by putative BCL2 inhibitors. Cell Death Differ. 2009, 16, 1030. [CrossRef] [PubMed]

147. Villalobos-Ortiz, M.; Ryan, J.; Mashaka, T.N.; Opferman, J.T.; Letai, A. BH3 profiling discriminates on-target small molecule BH3 mimetics from putative mimetics. Cell Death Differ. 2019, 1-9. [CrossRef] [PubMed]

148. Perimenis, P.; Galaris, A.; Voulgari, A.; Prassa, M.; Pintzas, A. IAP antagonists Birinapant and AT-406 efficiently synergise with either TRAIL, BRAF, or BCL-2 inhibitors to sensitise BRAFV600E colorectal tumour cells to apoptosis. BMC Cancer 2016, 16, 624. [CrossRef]

149. Kearney, C.J.; Lalaoui, N.; Freeman, A.J.; Ramsbottom, K.M.; Silke, J.; Oliaro, J. PD-L1 and IAPs co-operate to protect tumors from cytotoxic lymphocyte-derived TNF. Cell Death Differ. 2017, 24, 1705. [CrossRef]

150. Beug, S.T.; Beauregard, C.E.; Healy, C.; Sanda, T.; St-Jean, M.; Chabot, J.; Walker, D.E.; Mohan, A.; Earl, N.; Lun, X.; et al. Smac mimetics synergize with immune checkpoint inhibitors to promote tumour immunity against glioblastoma. Nat. Commun. 2017, 8, 1-15. [CrossRef]

151. Kearney, C.J.; Vervoort, S.J.; Hogg, S.J.; Ramsbottom, K.M.; Freeman, A.J.; Lalaoui, N.; Pijpers, L.; Michie, J.; Brown, K.K.; Knight, D.A.; et al. Tumor immune evasion arises through loss of TNF sensitivity. Sci. Immunol. 2018, 3, 3451. [CrossRef]

152. Zaretsky, J.M.; Garcia-Diaz, A.; Shin, D.S.; Escuin-Ordinas, H.; Hugo, W.; Hu-Lieskovan, S.; Torrejon, D.Y.; Abril-Rodriguez, G.; Sandoval, S.; Barthly, L.; et al. Mutations associated with acquired resistance to PD-1 blockade in melanoma. New Engl. J. Med. 2016, 375, 819-829. [CrossRef]

153. Vredevoogd, D.W.; Kuilman, T.; Ligtenberg, M.A.; Boshuizen, J.; Stecker, K.E.; de Bruijn, B.; Krijgsman, O.; Huang, X.; Kenski, J.C.; Lacroix, R.; et al. Augmenting Immunotherapy Impact by Lowering Tumor TNF Cytotoxicity Threshold. Cell 2019, 178, 585-599. [CrossRef]

154. Michie, J.; Kearney, C.J.; Hawkins, E.D.; Silke, J.; Oliaro, J. The Immuno-Modulatory Effects of Inhibitor of Apoptosis Protein Antagonists in Cancer Immunotherapy. Cells 2020, 9, 207. [CrossRef]

155. Laukens, B.; Jennewein, C.; Schenk, B.; Vanlangenakker, N.; Schier, A.; Cristofanon, S.; Zobel, K.; Deshayes, K.; Vucic, D.; Jeremias, I.; et al. Smac mimetic bypasses apoptosis resistance in FADD-or caspase-8-deficient cells by priming for tumor necrosis factor $\alpha$-induced necroptosis. Neoplasia (New York NY) 2011, $13,971$. [CrossRef] [PubMed]

156. Fulda, S. Exploiting inhibitor of apoptosis proteins as therapeutic targets in hematological malignancies. Leukemia 2012, 26, 1155-1165. [CrossRef] [PubMed]

157. Steinwascher, S.; Nugues, A.-L.; Schoeneberger, H.; Fulda, S. Identification of a novel synergistic induction of cell death by Smac mimetic and HDAC inhibitors in acute myeloid leukemia cells. Cancer Lett. 2015, 366, 32-43. [CrossRef] [PubMed]

158. McComb, S.; Aguadé-Gorgorió, J.; Harder, L.; Marovca, B.; Cario, G.; Eckert, C.; Schrappe, M.; Stanulla, M.; von Stackelberg, A.; Bourquin, J.-P.; et al. Activation of concurrent apoptosis and necroptosis by SMAC mimetics for the treatment of refractory and relapsed ALL. Sci. Transl. Med. 2016, 8, 339-370. [CrossRef]

159. Dixon, S.J.; Stockwell, B.R. The role of iron and reactive oxygen species in cell death. Nat. Chem. Biol. 2014, 10, 9. [CrossRef] 
160. Han, D.; Ybanez, M.D.; Ahmadi, S.; Yeh, K.; Kaplowitz, N. Redox regulation of tumor necrosis factor signaling. Antioxid. Redox Signal. 2009, 11, 2245-2263. [CrossRef]

161. Seyfrid, M.; Marschall, V.; Fulda, S. Reactive oxygen species contribute toward Smac mimetic/temozolomide-induced cell death in glioblastoma cells. Anti-Cancer Drugs 2016, 27, 953-959. [CrossRef]

162. Hugle, M.; Czaplinski, S.; Habermann, K.; Vogler, M.; Fulda, S. Identification of Smac mimetics as novel substrates for p-glycoprotein. Cancer Lett. 2019, 440, 126-134. [CrossRef]

163. Talbott, R.L.; Borzilleri, R.M.; Chaudhry, C.; Fargnoli, J.; Shen, H.; Fairchild, C.; Barnhart, B.; Ortega, M.; McDonagh, T.E.; Vuppugalla, R.; et al. Pharmacology of smac mimetics; chemotype differentiation based on physical association with caspase regulators and cellular transport. Exp. Cell Res. 2015, 338, 251-260. [CrossRef]

164. Adams, J. The proteasome: A suitable antineoplastic target. Nat. Rev. Cancer 2004, 4, 349. [CrossRef]

165. Silke, J.; Miasari, M.; Puthalakath, H. Ubiquitylation and Cancer Development. Curr. Cancer Drug Targets 2008, 8, 118-123. [CrossRef] [PubMed]

166. Hannan, R.D.; Drygin, D.; Pearson, R.B. Targeting RNA polymerase I transcription and the nucleolus for cancer therapy. Expert Opin. Ther. Targets 2013, 17, 873-878. [CrossRef] [PubMed]

167. Bywater, M.J.; Poortinga, G.; Sanij, E.; Hein, N.; Peck, A.; Cullinane, C.; Wall, M.; Cluse, L.; Drygin, D.; Anderes, K.; et al. Inhibition of RNA polymerase I as a therapeutic strategy to promote cancer-specific activation of p53. Cancer Cell 2012, 22, 51-65. [CrossRef] [PubMed]

(C) 2020 by the authors. Licensee MDPI, Basel, Switzerland. This article is an open access article distributed under the terms and conditions of the Creative Commons Attribution (CC BY) license (http://creativecommons.org/licenses/by/4.0/). 